\title{
Toxicological Impact of Cadmium and Copper Exposure in H. Exemplaris
}

\author{
Opeyemi Oluwadamilola Ojekunle, Ph.D. \\ Department of Environmental and Interdisciplinary Science \\ Texas Southern University, Houston, Texas, USA \\ Tel: 1-713-313-7108Ｅ-mail: opeoje91@gmail.com
}

Damola Olatoregun, Ph.D.

Department of Environmental and Interdisciplinary Science

Texas Southern University, Houston, Texas, USA

Tel: 1-713-313-7108Ｅ-mail: damolaolatoregun@gmail.com

\begin{abstract}
Sonya Good, Ph.D.
Department of Chemistry, Texas Southern University, Houston, Texas, USA

Tel: 1-713-313-1914Ｅ-mail: sonya.good@tsu.edu
\end{abstract}

Ayodotun Sodipe, Ph.D. (Corresponding author)

Department of Biology, Texas Southern University, Houston, Texas, USA

Tel: 1-832-382-2649 E-mail: ayodotun.sodipe@tsu.edu

Received: January 6, 2022 Accepted: February 1, 2021 Published: February 7, 2022

doi:10.5296/emsd.v11i2.19434 URL: https://doi.org/10.5296/emsd.v11i2.19434

\begin{abstract}
Cadmium and Copper are both heavy metals of concern and toxic environmental contaminants. Due to copper's excellent electrical conductivity, its most common use is in electrical equipment. Cadmium on the other hand, is not essential, although it is used majorly in batteries. Contamination with cadmium and copper metals stems mainly from
\end{abstract}


anthropogenic activities but other natural sources also exist. Tardigrades are microscopic aquatic animals renowned for their tolerance towards extreme environmental conditions, this study is to investigate their tolerance towards heavy metals and how to ameliorate the potential hazardous effects with an antioxidant (Selenium). Antioxidants are substances that may protect the cells against the effects of free radicals, they are intimately involved in the prevention of cellular damage: the common pathway for cancer, aging, and some diseases. We hypothesized that Hypsibius exemplaris (H. exemplaris) has a low tolerance to a high concentration of toxicants and if Reactive Oxygen Species is released, some enzymatic pathways will be altered, but a certain concentration of Selenium will abate this effect, confirming the antioxidative capacity of Selenium. As was observed, cadmium and copper solutions increased Tardigrade sensitivity to oxidative stress as well as significantly reduced metabolism was observed. The produced reactive oxygen species was confirmed with fluorescence microscopy. Treating the exposed tardigrades with $0.5 \mathrm{ppm}$ of selenium using sodium selenite counteracted the cadmium and copper induced reactive oxygen species produced. The antioxidative enzymes produced were quantified using various assay methods. In conclusion, from an environmental perspective, selenium is a relevant antioxidant using the appropriate dosage.

Keywords: Cadmium, Copper, Reactive oxygen species, Antioxidant, Enzyme assay

\section{Introduction}

\subsection{Environmental Contamination}

Industrial revolution which took place between the $18^{\text {th }}$ and $19^{\text {th }}$ century was responsible for the majority of the current environmental contamination and ecological disruption of the aquatic ecosystem. As a result of anthropogenic disturbances and urbanization, there are huge discharge of contaminants like, pesticides, pharmaceutical waste, detergents, sewage and heavy metals.

\subsection{Heavy Metals}

Heavy metals are non-photodegradable and non-biodegradable, these characteristics of heavy metals make their toxicity highly persistent consequently having an easy environmental bioaccumulation (Liu et al. 2019; Valdés et al. 2014). It is important to effectively monitor the accumulation of heavy metals in aquatic ecosystem (Ahmed et al., 2015) because there is a tendency for the transference and biomagnification of heavy metal through food chains, which would consequently be a threat to public health (Liu et al., 2017c). The presence of heavy metals such as chromium, mercury, lead, and copper $(\mathrm{Cu})$, even in trace concentrations, in soil, water and atmosphere can cause serious health implications. Heavy metals are naturally emitted into the environment through, volcanic eruptions, earthquake, and other natural hazards but the quantity of heavy metals released through mobile and stationary sources exceeds the natural rate of emission (Iheanacho et al., 2017). In recent times, most industrial activities make use of metals, for machines, utensils, walls, and a variety of other uses. Cadmium $(\mathrm{Cd})$ and $\mathrm{Cu}$ are two of the more commonly used heavy metals (Martín-Folga et al., 2019). ATSDR 2012 labelled cadmium as a heavy metal of very great concern due to its 
different known effects.

\subsection{Cadmium and Copper}

$\mathrm{Cd}$ is highly water soluble; this characteristic increases its bioaccumulation in aquatic organisms (Zhou et al., 2019) consequently, posing threats to their existence (Yang et al., 2015; Zhou et al., 2019). In the studies carried out by Wang et al (2019); Mao et al (2007) and Liu et al (2017) on crustaceans and aquatic species, it was discovered that $\mathrm{Cd}$ reduces growth and survival. It furthermore results to a decline in population growth. $\mathrm{Cu}$ is known to be an essential micronutrient to marine organisms as well as a toxicant when exceeding a critical concentration (Zitoun et al. 2019). The toxicity of $\mathrm{Cu}$ is directly related to the $\mathrm{Cu}$ concentration that is bioavailable (Hassler et al., 2007), rather than the concentration of dissolved $\mathrm{Cu}$ in solution (Hassler et al., 2007). Chronic exposure to $\mathrm{Cu}$ can lead to adverse effects on survival, growth, reproduction as well as alterations of brain function, enzyme activity, blood chemistry, and metabolism. The World Health Organization (WHO) has set $3 \mathrm{ppb}$ as the maximum limit allowable for $\mathrm{Cd}$ in freshwater while the maximum allowable limit for $\mathrm{Cu}$ is 2ppm (WHO, 2018). Approaches to minimize the natural and anthropogenic exposures to these heavy metals are important since they are non-biodegradable or photodegradable. Some of these approaches include herbal absorption of heavy metal deposit to neutralize the soil. This method was confirmed by Singh et al., 2011 in their study explaining how the use of herbal medicine has become the major form of treatment in developing countries in recent years. Substitution of elements involved in industrial, or mining activities can also reduce exposure to these metals. In jewelry making, for example, pure silver can replace the use of silver-cadmium, zinc, nickel, tin can also replace $\mathrm{Cd}$ in plating (COWI, 2003).

\subsection{Tardigrades}

Tardigrades also known as Water bears were first discovered in 1773 Macdonald, 2004 Phylum Tardigrada are minute invertebrates belonging to the supertype Articulata. They can be found all over the Earth and can inhabit very diverse environments (soil, water bodies, and mountaintops). Water bears are small, cylindrical invertebrates, up to $2.1 \mathrm{~mm}$ in length, the tardigrade body is covered with a flexible cuticle, which is smooth or covered with gibbosities, spines or plates. They are divided into five segments, with the first segment being the head and the next four each have one pair of unsegmented legs ending in claws. Their internal structure includes a complete digestive system that feeds on algae, bacteria, fungal cells and other tardigrades; a well-developed nervous system consisting of rings around mouth (brain) and an abdominal chain with segmental ganglia. They also have various sensory organs like papilla, chemoreceptors and eyes. The reproduction can be dioecious and bisexual; fertilization can be external or internal. The eggs are covered with an additional shell, the smooth or ornamented chorion, and are laid directly into the environment. Terrestrial species can be found in mosses, lichens and soil where they are threatened by drying. In this situation, terrestrial species need a thin water film around their bodies in order to stay active. Formation of tun help to control the drying up of the internal and external organs (Weronika et al. 2017). 


\section{Macrothink

\subsection{Selenium}

Selenium is an antioxidant that prevents the formation and/or removes oxidative stress. It plays an important role in reducing the damage caused by reactive oxygen species (ROS) to the cell (Wang et al. 2019). Selenium exists as organic and inorganic forms. Organic selenium has higher bioavailability in improving growth (Küçükbay et al. 2009) and antioxidant capacity (Wang et al. 2007). Environmental Protection Agency (EPA) has set a maximum contaminant level (MCL) at $0.05 \mathrm{mgL}^{-1}$ or $50 \mathrm{ppb}$ for environmental selenium. This value is set based on the best available science to prevent potential health problems. Some states, however, may set more stringent drinking water MCL for selenium than EPA (EPA, 2015).

Considering what is known about selenium, we postulated that when ROS is released, some enzymatic pathways will be altered, but a certain concentration of Selenium will abate this effect, confirming the antioxidative capacity of Selenium. Thus, the objectives of this study were to evaluate the toxic effect of $\mathrm{Cd}$ and $\mathrm{Cu}$ in the formation of free radicals, cytotoxic stress and perform enzymatic assay to determine the effect of the exposure on Superoxide Dismutase (SOD), catalase (CAT) and acetylcholine (Ach).

\section{Materials and Methods}

\subsection{Tardigrade Culture}

We selected adult Tardigrades for further testing, and they were cultured in deionized water to simulate their natural environment. Following the culturing, we incubated the plates at room temperature.

\subsection{Heavy Metal Preparation}

\subsubsection{Copper}

Stock solution (2ppm) was prepared with $2 \mathrm{mg}$ of Copper (II) chloride hydrate in $1000 \mathrm{ml}$ of deionized water and serial dilution was carried out to get the other concentrations; $1 \mathrm{ppm}$, 0.8ppm, 0.6ppm, 0.4ppm, 0.2ppm, 0.1ppm and 0.05ppm.

\subsubsection{Cadmium}

Stock solution (1000ppb) was prepared with 1mg of Cadmium chloride hydrate in $1000 \mathrm{ml}$ of deionized water and serial dilution was carried out to get the other concentrations; $500 \mathrm{ppb}$, $250 \mathrm{ppb}, 100 \mathrm{ppb}, 50 \mathrm{ppb}, 5 \mathrm{ppb}, 2.5 \mathrm{ppb}, 2.0 \mathrm{ppb}, 1.5 \mathrm{ppb}, 1.0 \mathrm{ppb}, 0.5 \mathrm{ppb}, 0.1 \mathrm{ppb}, 0.05 \mathrm{ppb}$ and $0.025 \mathrm{ppb}$.

\subsection{Toxicity Testing}

Prior to $\mathrm{Cd}$ and $\mathrm{Cu}$ exposure, single tardigrades were collected from the stock culture under microscope using an ordinary laboratory pipette with plastic tip. We transferred the tardigrades to glass petri dish containing deionized water.

We then assigned tardigrades into groups of 50 in each plate and exposed to $2 \mathrm{ml}$ of a given $\mathrm{Cd}$ solution. The cadmium concentration in these solutions ranged from $\sim 0.025 \mathrm{ppb}$ to $500 \mathrm{ppb}$ (500ppb, 250ppb, 100ppb, 50ppb, 5ppb, 2.5ppb, 2.0ppb, 1.5ppb, 1.0ppb, 0.5ppb, 
$0.1 \mathrm{ppb}, 0.05 \mathrm{ppb}$ and $0.025 \mathrm{ppb}$ ) for periods of 2, 4, 6 and $24 \mathrm{~h}$ and $2 \mathrm{ml}$ of $\mathrm{Cu}$ solution was exposed to the experimental animal at various concentrations ranging between $0.05 \mathrm{ppm}$ and 2ppm $(0.05,0.1,0.2,0.4$, and $0.6 \mathrm{ppm})$ at 2, 4, 6 and $24 \mathrm{~h}$.

3. Results

Based on preliminary experiments, reactions that occur between 5 to 6 hours remain fixed, therefore 6 hours seemed sufficient to allow toxic effects of the $\mathrm{Cd}$ and $\mathrm{Cu}$ to occur.

\subsection{Toxic Effects of $\mathrm{Cd}$ and $\mathrm{Cu}$ Exposure on H. exemplaris}

Immediately following the exposure, $5 \mu \mathrm{l}$ of the dye was added to the plate and incubated for 30 minutes at $22^{\circ} \mathrm{C}$. After incubation, we transferred the tardigrades with a Pasteur pipette into 2-ml glass centrifuge tubes. They were washed by allowing the tardigrades to gravity settle into a pellet, removing the supernatant, adding $2.0 \mathrm{ml}$ of deionized water, gently mixing the tardigrades by creating bubbles with a Pasteur pipette and repeating the process for a total of three washes. We then transferred $2 \mathrm{ml}$ of the washed tardigrades ( $45-50$ tardigrades) to a glass petri dish.

Images were acquired using a Nikon Ti2 Eclipse inverted microscope with 4x objective lens and DS-Qi1Mc camera. Figures 1a-e are the fluorescence image of copper-exposed organisms, while figure 1f is the control plate. Figures $2 \mathrm{a}-\mathrm{f}$ are the fluorescence image of cadmium-exposed organisms, while figure $2 \mathrm{~g}$ is the control plate. Image capture was automated in Nikon NIS-Elements AR software to capture images of the tardigrades. The microscope software stores images in Nikon nd2 format. To begin analysis, we converted the file format to TIFF images with the filenames identifying the concentration and duration of exposure (Melstrom et al. 2007).

\subsection{Fluorescence Imaging}

Interestingly, the fluorescent image seemed to be observed in almost all the concentrations, though the brightness is greatly reduced (Figure $3 \mathrm{a}-\mathrm{b}$ ) and this can be explained by the research conducted by Mittler, which stated that ROS are essential for promoting normal cellular processes, as opposed to having a toxic effect on life.

Hydrogen peroxide $3 \%$ was introduced to the Tardigrade as a positive control and a very bright fluorescence was observed after $2 \mathrm{~h}$ (Figure 4). 


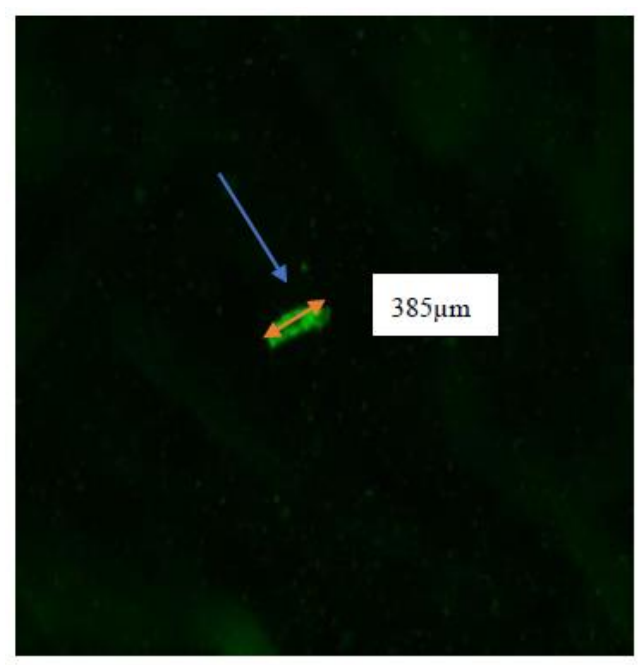

Figure 1a. Fluorescence at $0.4 \mathrm{ppm}$ of $\mathrm{Cu}$ after $4 \mathrm{hr} \mathrm{Mg}(4 \mathrm{X})$

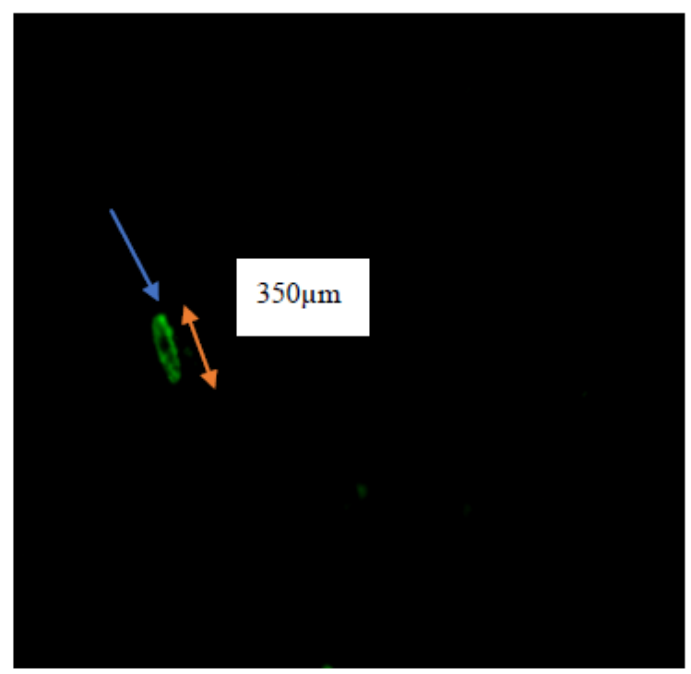

Figure 1b. Fluorescence at $0.4 \mathrm{ppm}$ of $\mathrm{Cu}$ after $6 \mathrm{hr} \mathrm{Mg}(4 \mathrm{X})$

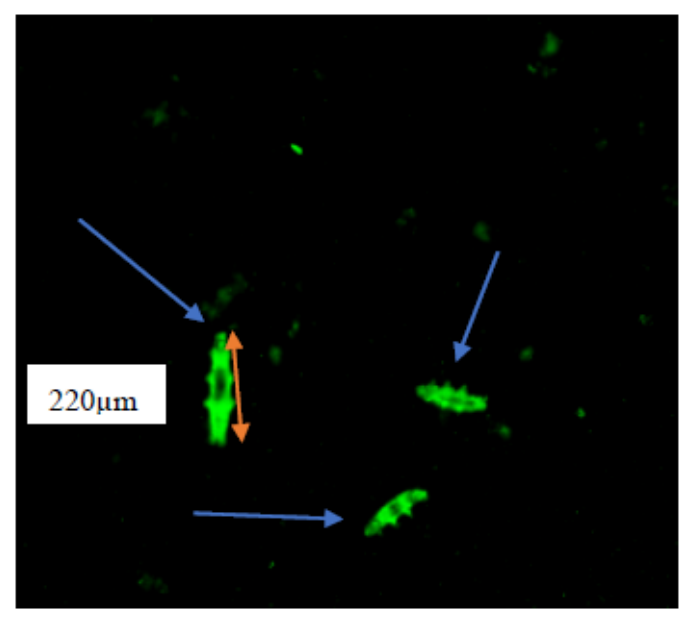

Figure 1c. Fluorescence at $0.4 \mathrm{ppm}$ of $\mathrm{Cu}$ after $24 \mathrm{hr} \mathrm{Mg}(40 \mathrm{X})$ 


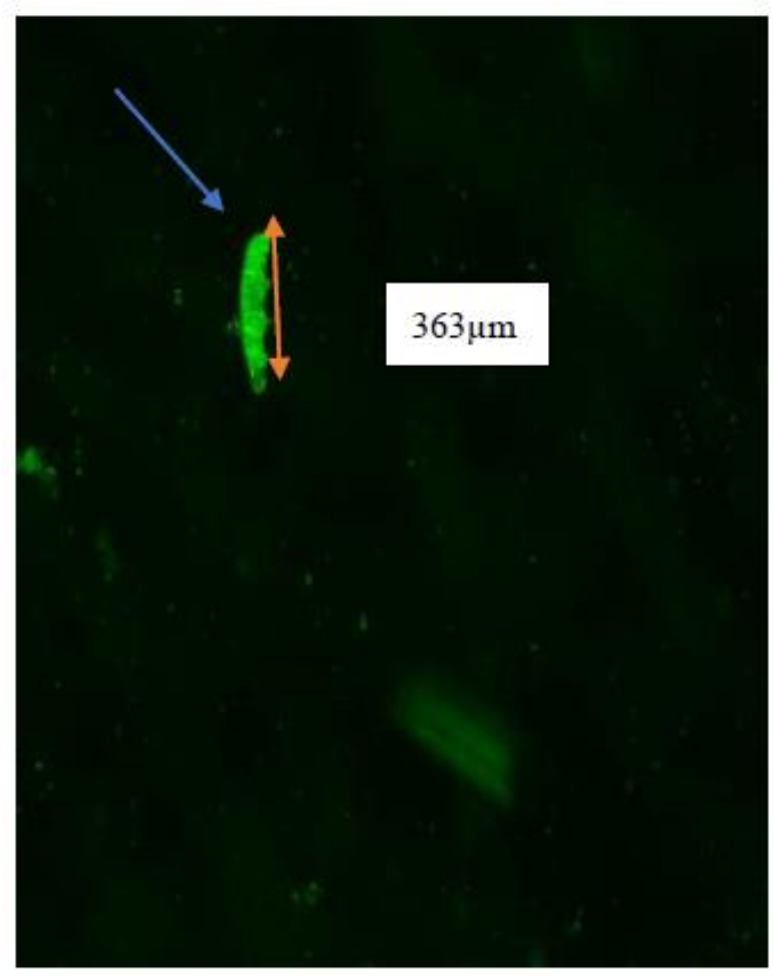

Figure 1d. Fluorescence at $0.6 \mathrm{ppm}$ of $\mathrm{Cu}$ after $4 \mathrm{hr} \mathrm{Mg}(4 \mathrm{X})$

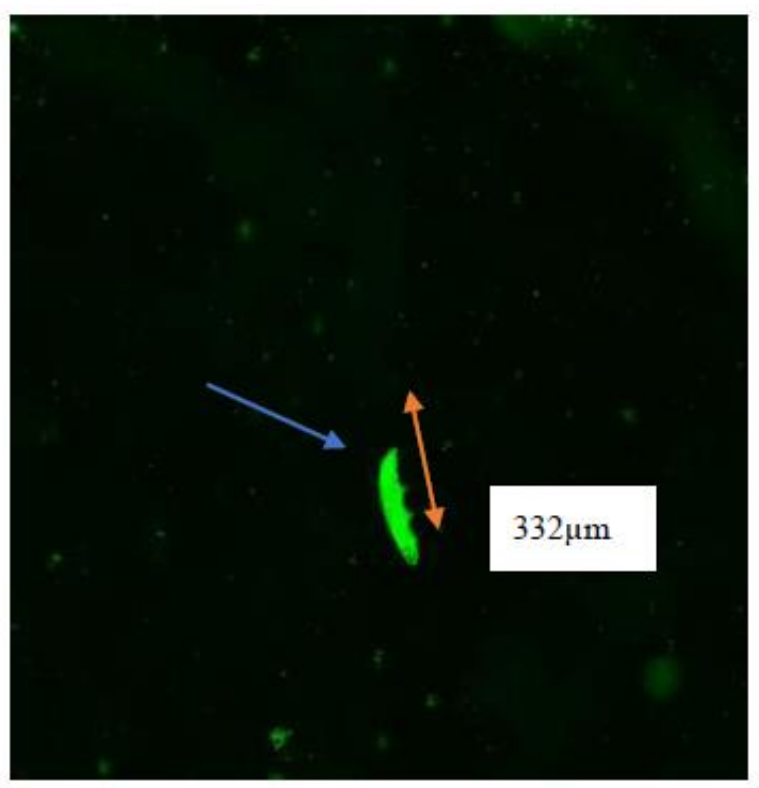

Figure 1e. Fluorescence at $0.6 \mathrm{ppm}$ of $\mathrm{Cu}$ after $6 \mathrm{hr} \mathrm{Mg}(4 \mathrm{X})$ 


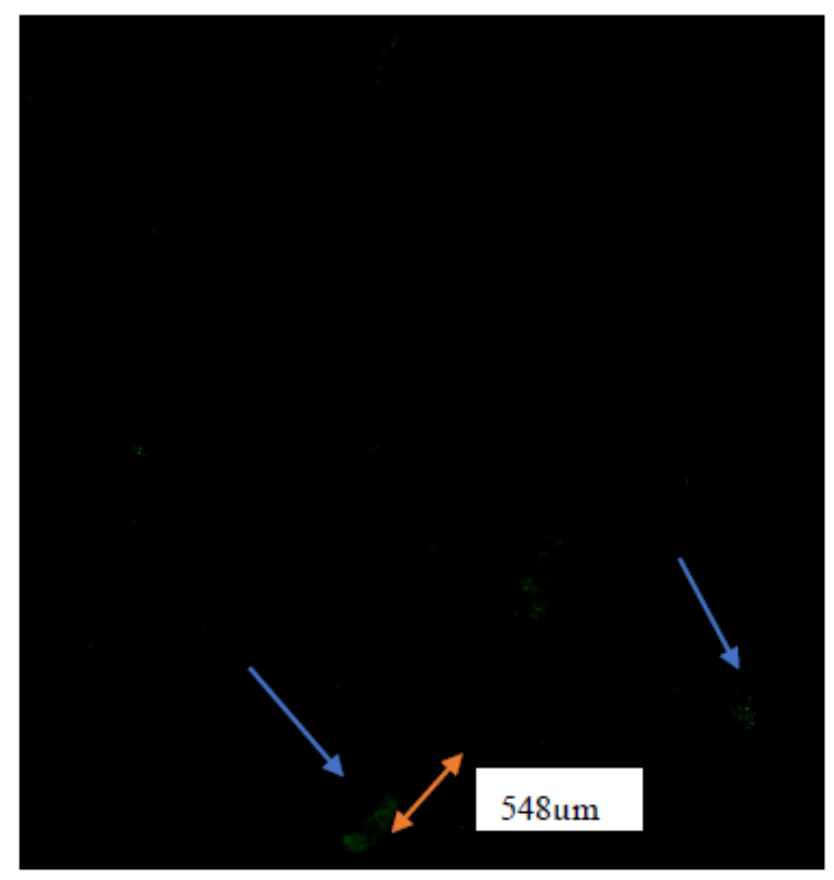

Figure 1f. Copper control, No Fluorescence $\operatorname{Mg}(4 \mathrm{X})$

Figure 1: Exposed to Copper concentrations, the metabolic activities of tardigrades were observed, with activities decreasing, over time, the morphology was also noticed to be affected as the body size reduced as the exposure time increased. (A) Fluorescence was produced after $4 \mathrm{hr}$ of exposure to $0.4 \mathrm{ppm}$. (B) The fluorescence increased after $6 \mathrm{hr}$ and (C) highest after $24 \mathrm{hr}$ when the metabolic activity was down to about $20 \%$. (D) Exposure to $0.6 \mathrm{ppm}$ for $4 \mathrm{~h}$ with a high fluorescence when compared with the control $(\mathrm{F})$, interestingly, the fluorescence kept increasing and at (E) 6hr, the metabolic activity was down to $20 \%$.

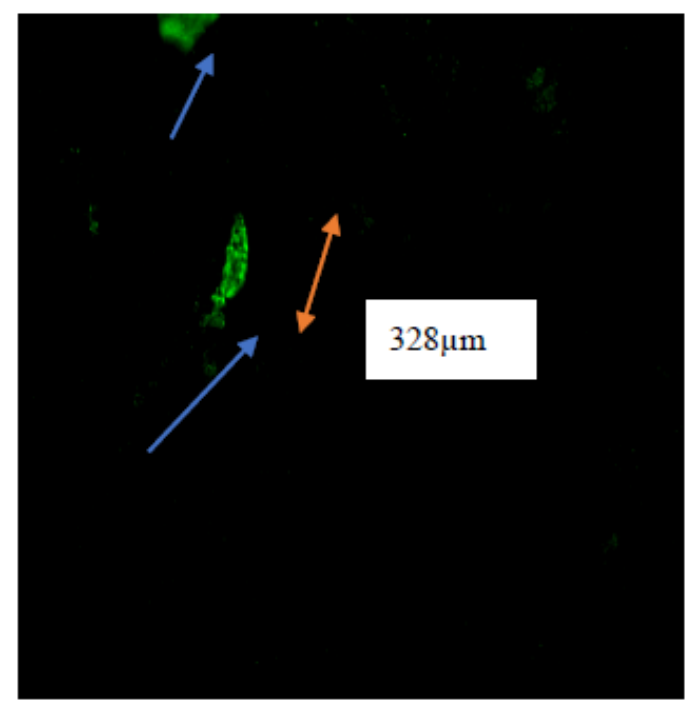

Figure 2a. Fluorescence at $0.5 \mathrm{ppb}$ of $\mathrm{Cd}$ after $6 \mathrm{hr} \mathrm{Mg}(4 \mathrm{X})$ 


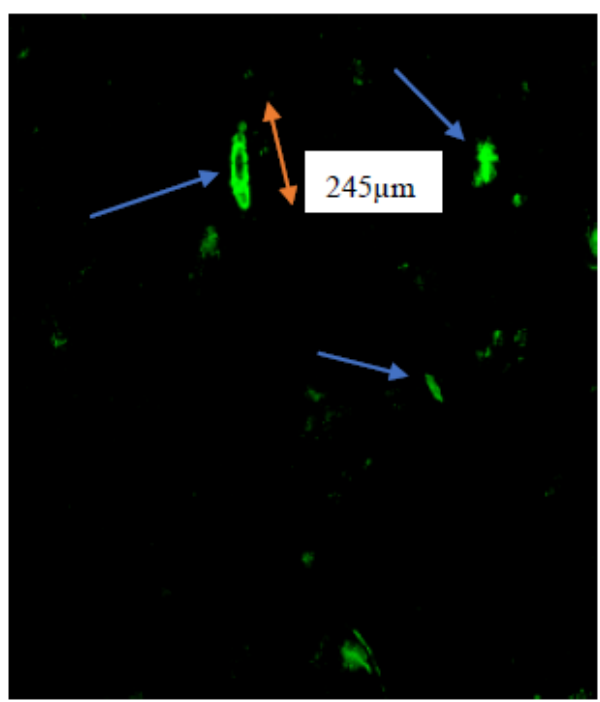

Figure 2b. Fluorescence at $0.5 \mathrm{ppb}$ of Cd after $24 \mathrm{hr} \mathrm{Mg}(40 \mathrm{X})$

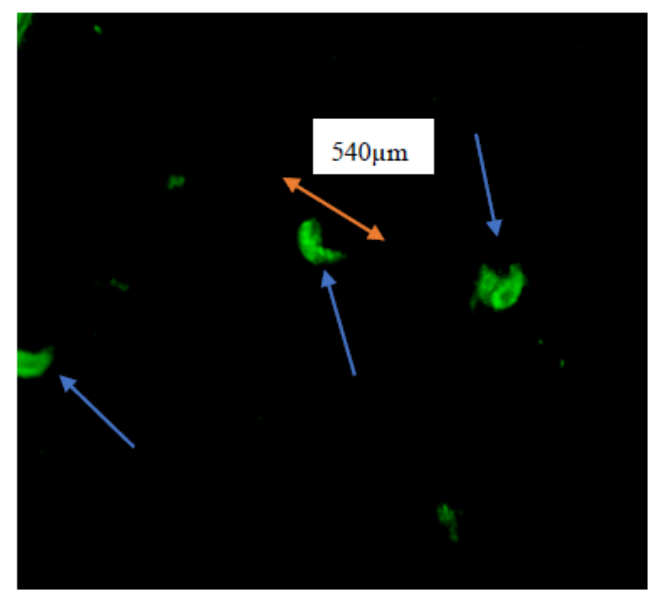

Figure 2c. Fluorescence at 1.0ppb of Cd after $2 \mathrm{hr} \operatorname{Mg}(4 \mathrm{X})$

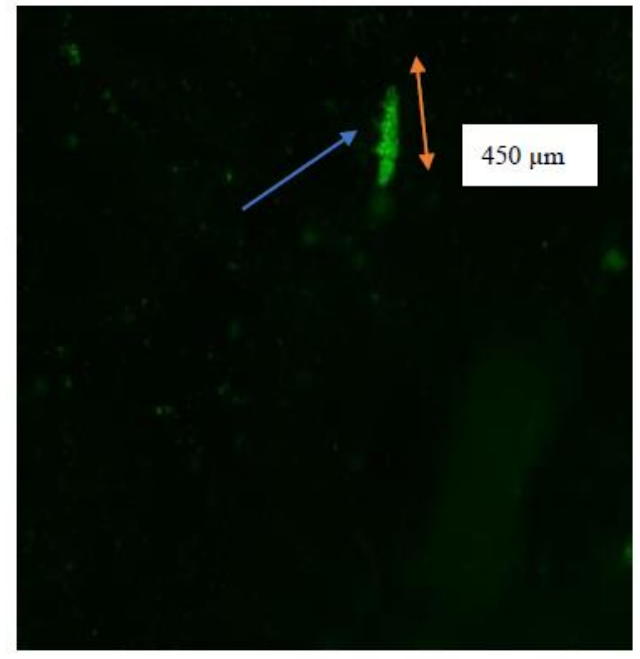

Figure 2d. Fluorescence at 1.0ppb of Cd after $4 \mathrm{hr} \operatorname{Mg}(4 \mathrm{X})$ 


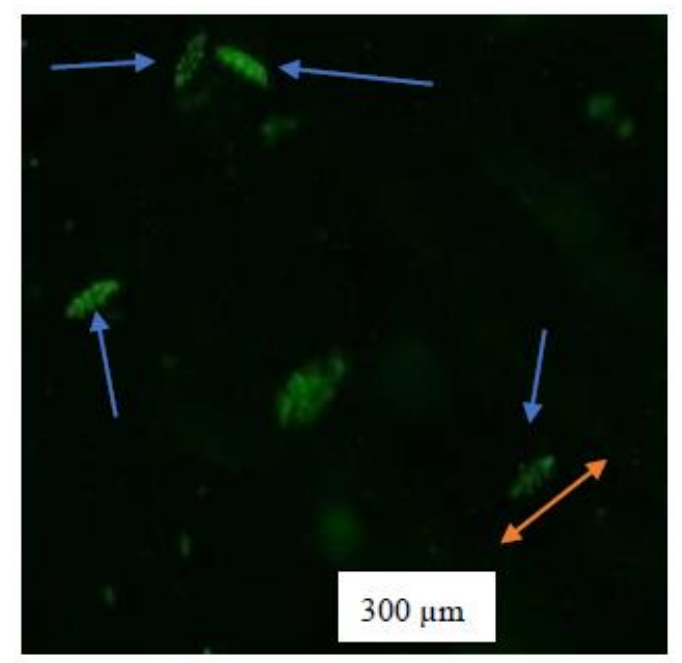

Figure 2e. Fluorescence at 1.0ppb of Cd after $6 \mathrm{hr} \operatorname{Mg}(4 \mathrm{X}) \mathrm{s}$

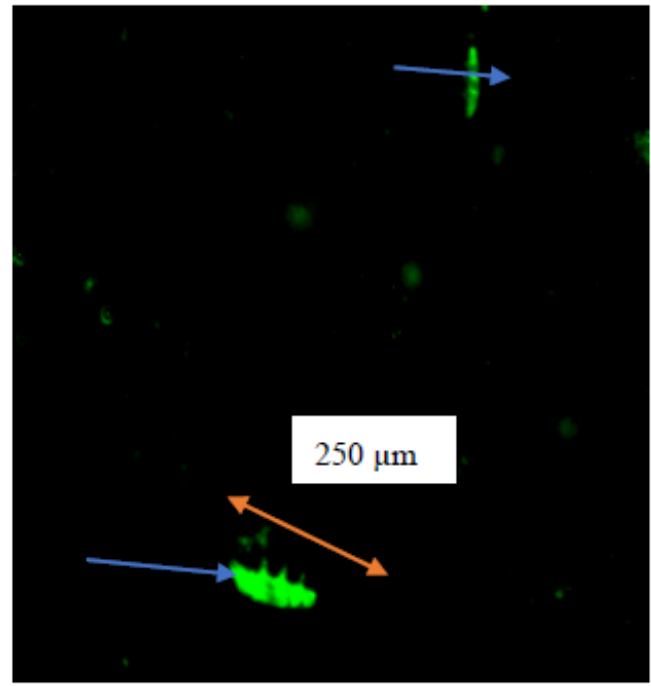

Figure 2f. Fluorescence at 1.0ppb of Cd after $24 \mathrm{hr} \mathrm{Mg}(40 \mathrm{X})$

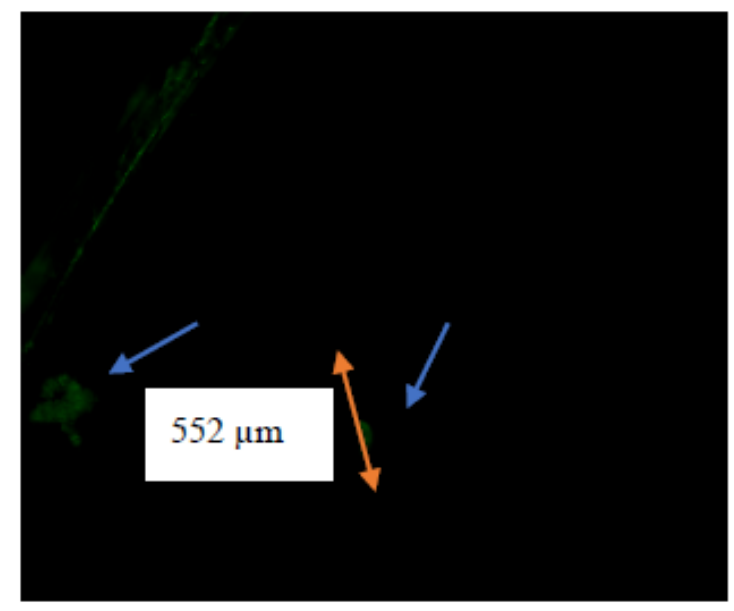

Figure 2g. Cadmium control, No Fluorescence $\operatorname{Mg}(4 \mathrm{X})$ 


\section{IMacrothink \\ Environmental Management and Sustainable Development \\ ISSN 2164-7682 2022, Vol. 11, No. 2}

Figure 2: After exposure to increasing Cadmium concentrations, we observed a gradual decline in the metabolic activities of tardigrades as the time of exposure increased. Morphologically, it was observed that the body size gradually reduced as the concentration and duration of exposure increased. (A) Fluorescence was produced after $6 \mathrm{hr}$ of exposure to $0.5 \mathrm{ppb}$. (B) The fluorescence increased after $24 \mathrm{hr}$ and (C) after $2 \mathrm{hr}$ of exposure to $1.0 \mathrm{ppb}$, the metabolic activity was relatively good but after (D) Exposure to $1.0 \mathrm{ppb}$ for $4 \mathrm{hr}$ the fluorescence increased and highest at (E) 1.0ppb after 6hr and metabolic activity down at (F) $1.0 \mathrm{ppb}$ after $24 \mathrm{hr}$ when compared with the control $(\mathrm{G})$.

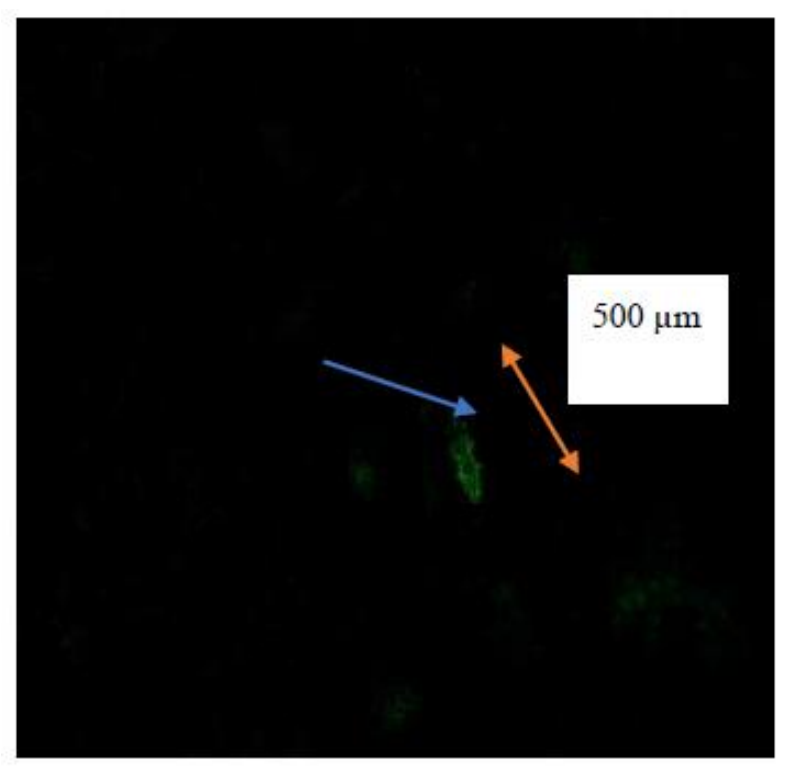

Figure 3a. Fluorescence at $0.025 \mathrm{ppb}$ of Cd after $24 \mathrm{hr} \mathrm{Mg}(40 \mathrm{X})$

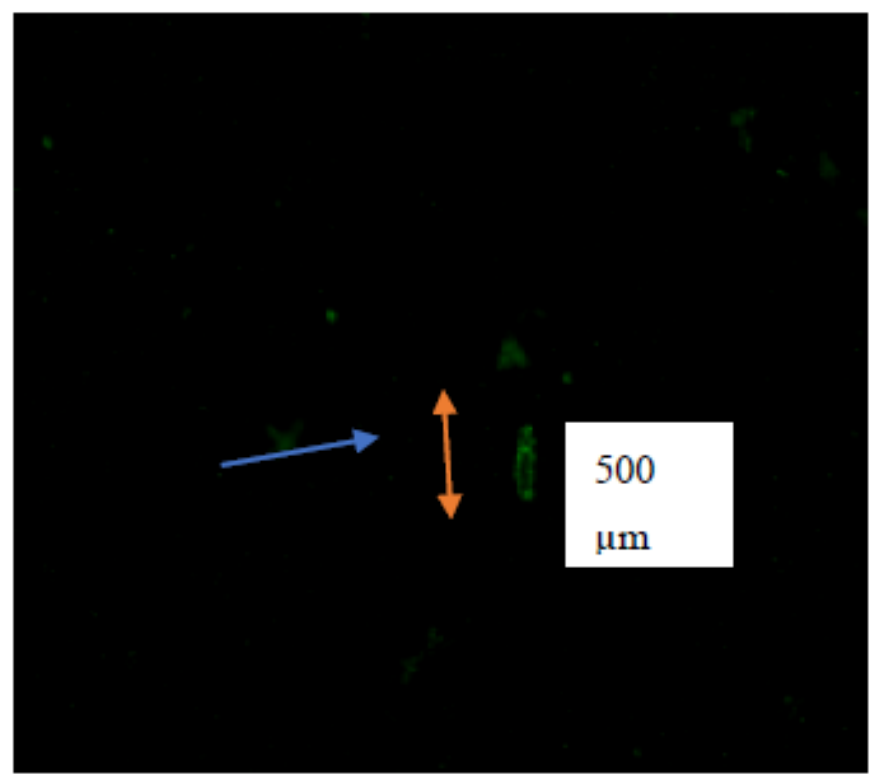

Figure 3b. Fluorescence at $0.05 \mathrm{ppb}$ of $\mathrm{Cd}$ after $24 \mathrm{hr} \operatorname{Mg}(4 \mathrm{X})$ 


\section{Macrothink}

Figures 3: These confirmed that ROS was being produced in the Tardigrades even at minute concentrations, however, the stressed condition that led to the production of these ROS is not enough to alter the metabolic activity (A) and the morphology also remained the same (B) with the control Tardigrade. The orange arrow indicates the length of the tardigrades at various exposure concentrations

\subsection{Treatment with Selenium}

Prior to exposure of $H$. exemplaris to both $\mathrm{Cd}$ and $\mathrm{Cu}$ solutions, we added $1 \mathrm{ml}$ of $1 \mathrm{ppb} \mathrm{Se}$ solution to the $H$. exemplaris culture plates. Interestingly, there was no toxic effect from the point of exposure through the duration of exposure (graph 1-2, chart 1-2, Fig 5a-d). To confirm the actual concentrations that we treated, exposure to the cadmium concentrations $(0.5 \mathrm{ppb}$ and $1.0 \mathrm{ppb})$, copper concentrations $(0.4 \mathrm{ppm}$ and $0.6 \mathrm{ppm})$, Hydrogen peroxide solution $\left(\mathrm{H}_{2} \mathrm{O}_{2}\right)$ was done again and the same result was reported. There was not much difference in the activity of $H$. exemplaris at the Point of Exposure (POE) and after $6 \mathrm{~h}$ of exposure, when water was used as a treatment. It is suggested that water is not an effective treatment of production of ROS, but it most likely diluted the concentration of the cadmium and copper in the $H$. exemplaris culture plate, resulting in a decreased toxic effect on the $H$. exemplaris.

We added $1 \mathrm{ml}$ of $1 \mathrm{ppb}$ Se solution to the H. exemplaris as a positive control (Fig. 20), This result confirmed the antioxidative capacity of Se.

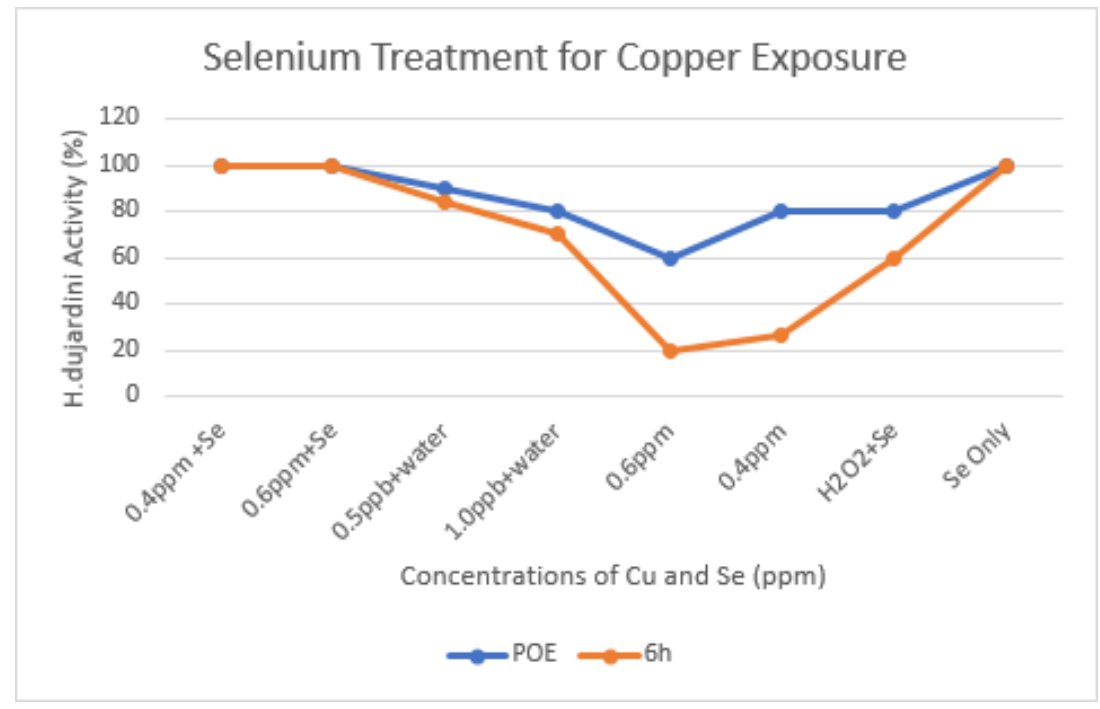

Graph 1. Selenium Treatment for Copper Exposure 


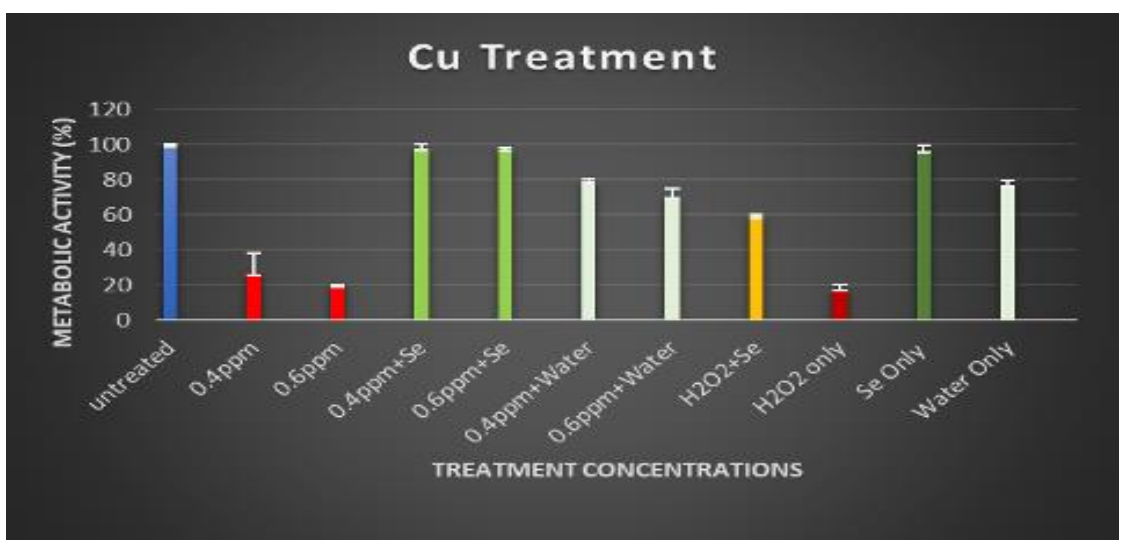

Chart 1. Selenium Treatment for Copper Exposure

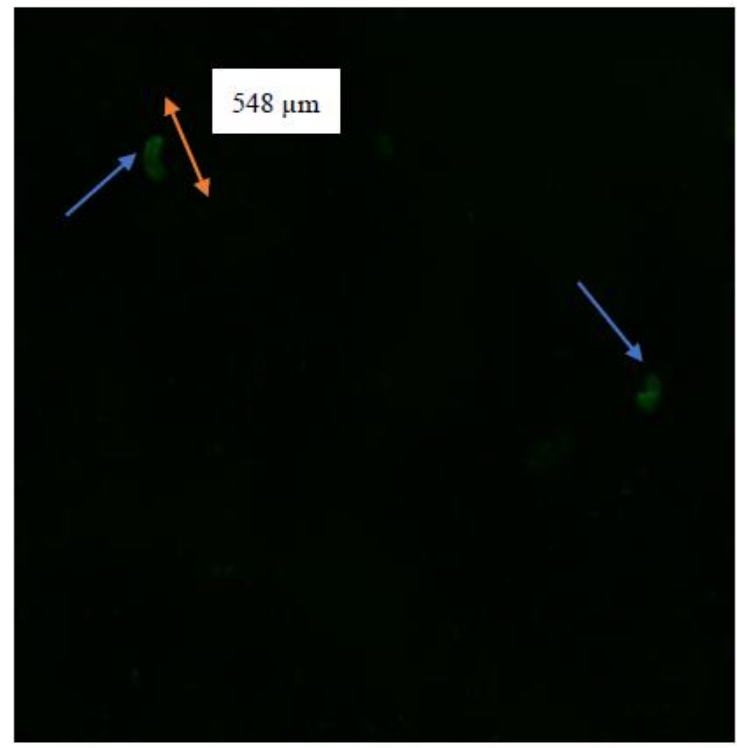

Figure 4a. Se $+0.4 \mathrm{ppm} \mathrm{Cu}$ after $6 \mathrm{hr} \mathrm{Mg}(\mathrm{X} 4)$

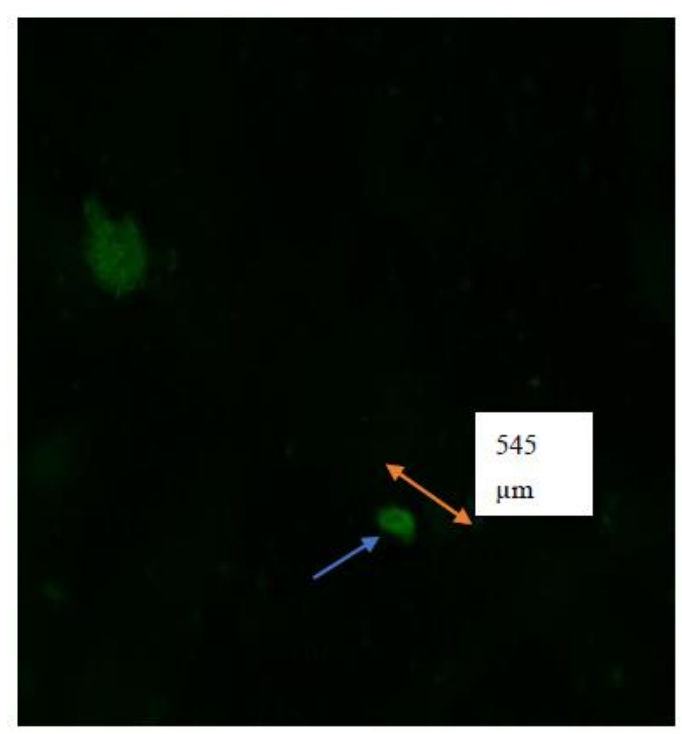

Figure 4b. Se+0.6ppm Cu after $6 \mathrm{~h}$ 


\section{Macrothink}

Environmental Management and Sustainable Development

ISSN 2164-7682 2022, Vol. 11, No. 2

Figure 4: Treatment with $1 \mathrm{ml}$ of $1.0 \mathrm{ppm}$ of Se showed that the metabolic activity peaked back to about $99 \%$ for the Tardigrade that was exposed to $0.4 \mathrm{ppm}$ copper (A) and the body size was relatively the same as the control Tardigrade for the tardigrade that was exposed to $0.6 \mathrm{ppm}$.

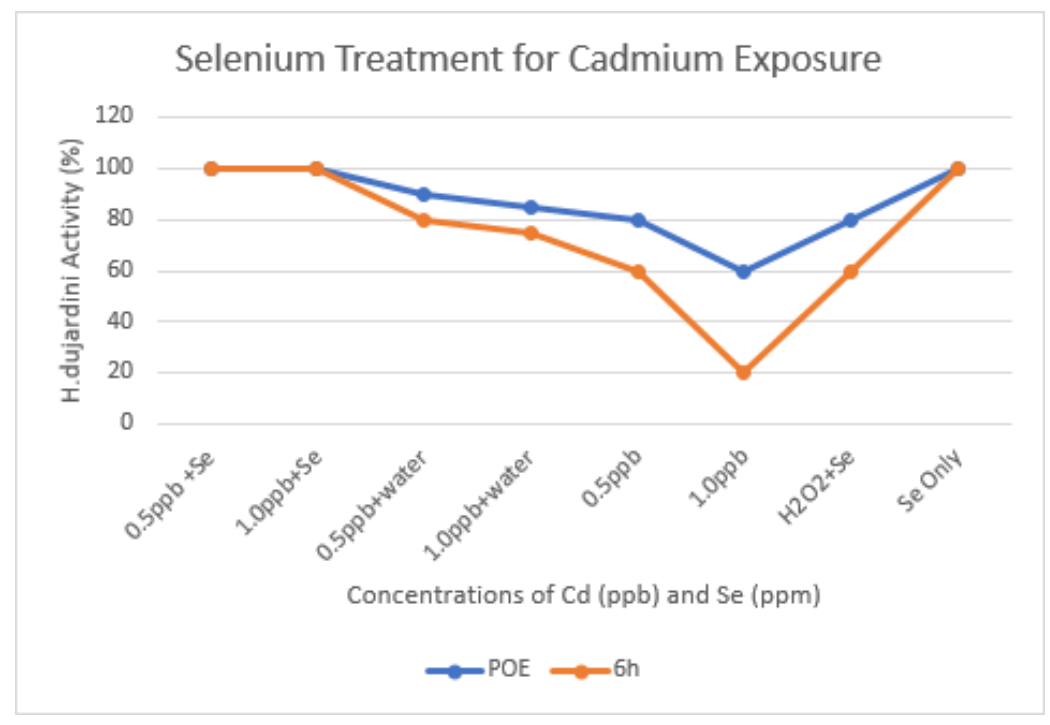

Graph 2. Selenium Treatment for Cadmium Exposure

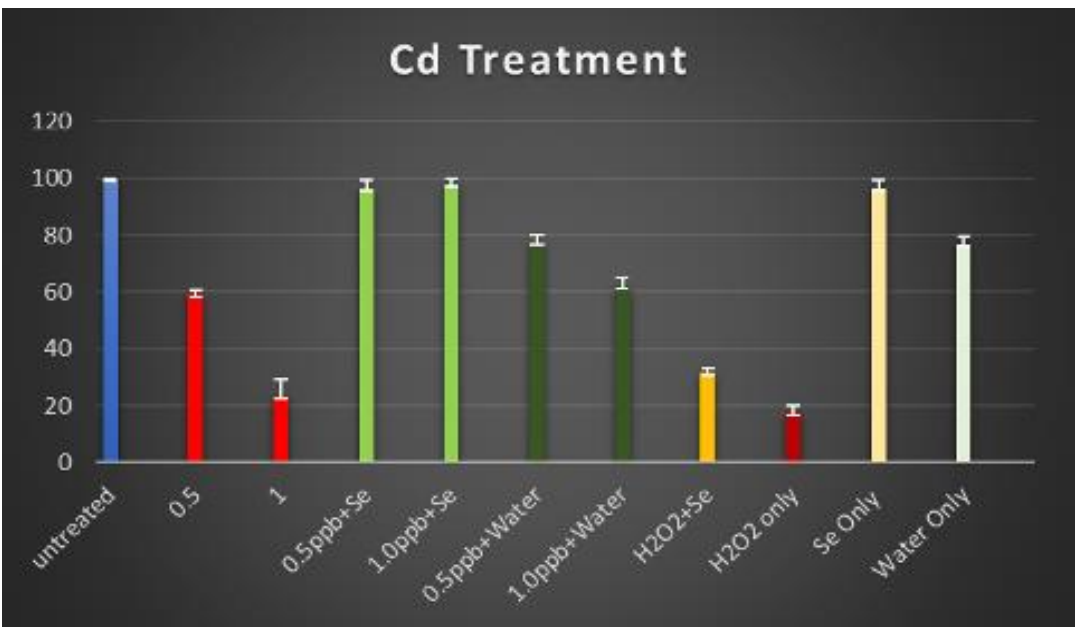

Chart 2. Selenium Treatment for Cadmium Exposure 


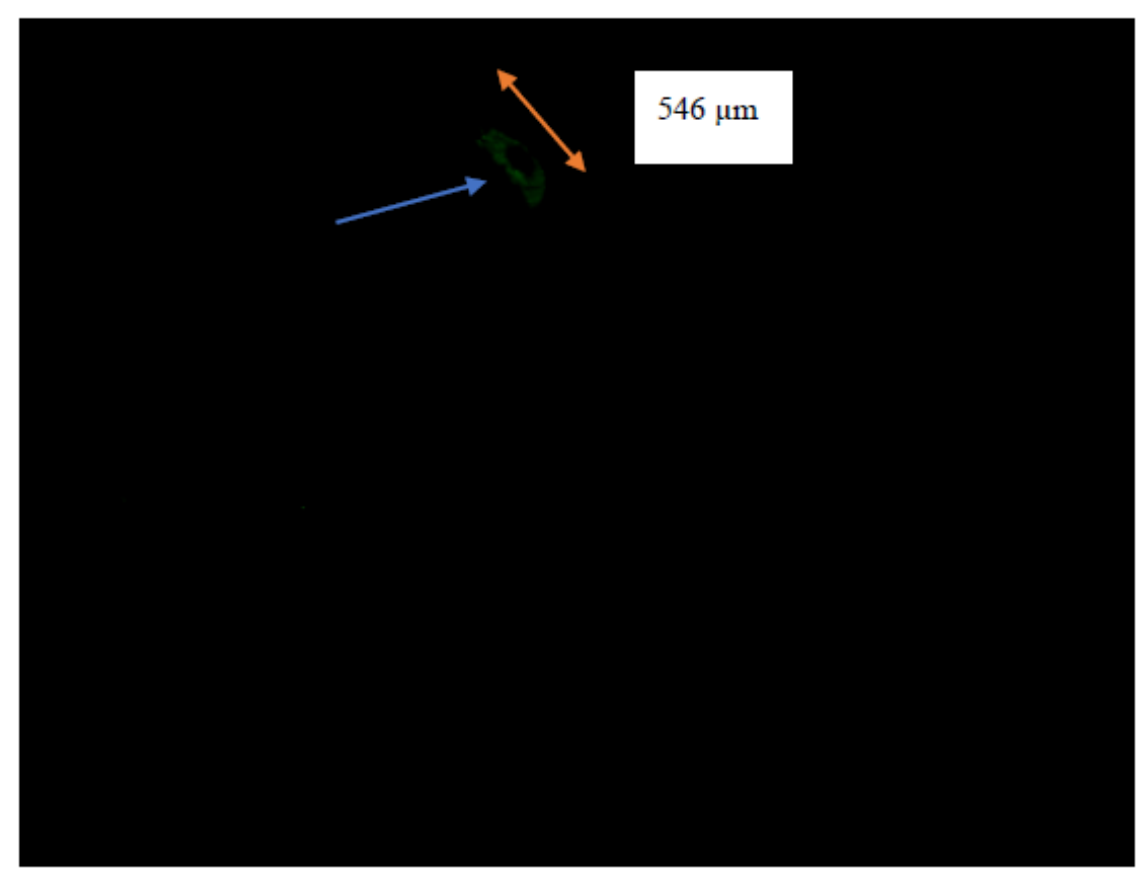

Figure 4c. Se+ 0.5ppb Cd after 6hr $\mathrm{Mg}(4 \mathrm{X})$

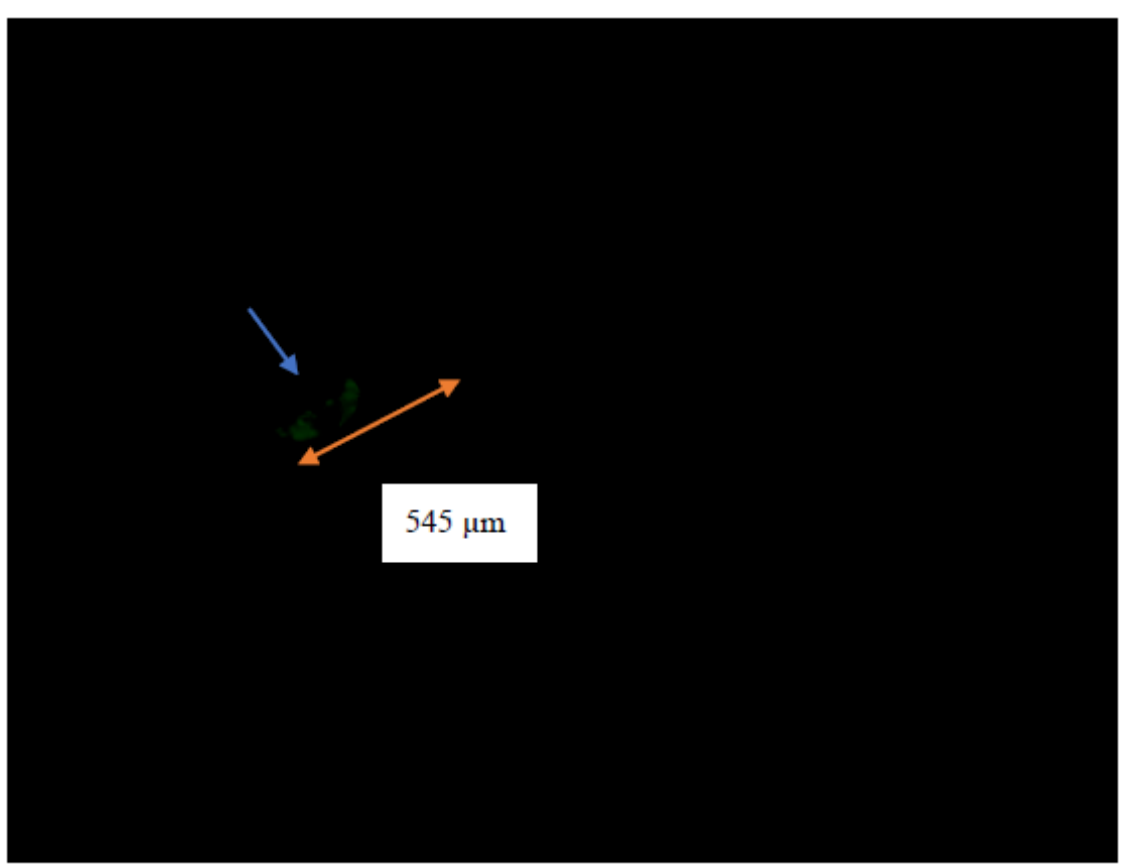

Figure 4d. Se+ 1.0ppb Cd after $6 \mathrm{~h} \mathrm{Mg}(4 \mathrm{X})$

\subsection{Quantification}

\subsubsection{SOD Assay}

The SOD activity assay was designed to quantitatively measure SOD activity in the treated 
tardigrades. The assay was carried out using the Superoxide Dismutase (SOD) Colorimetric Activity Kit (Thermofisher) with manufacturer's instruction for cells. Using a 96 well plate, the standards, experimental samples and treatments were plated. The plate was incubated for 20 minutes in room temperature and after gently mixing, the reaction mixture is monitored spectrophotometrically at $450 \mathrm{~nm}$ every 10 minute for $6 \mathrm{hrs}$ using a microplate reader. The value of absorbance reduced with increase in enzyme production, this result confirmed that the Se-treated organisms produced more antioxidative enzyme (SOD), due to the low absorbance reading (Chart 3-6 and Graph 3).

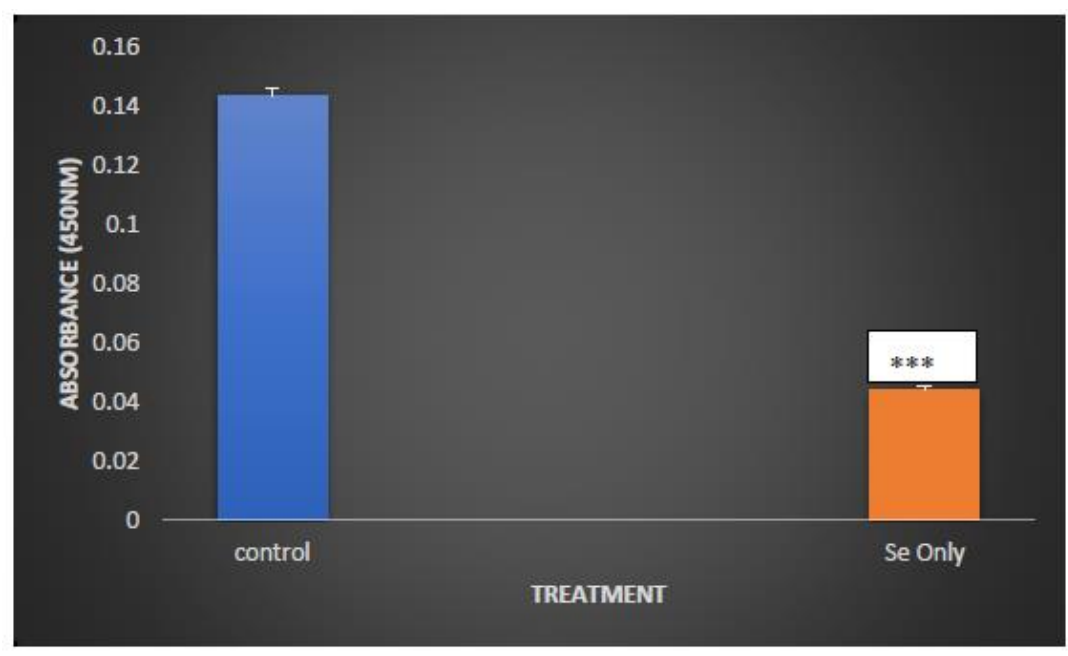

Chart 3. control against Se (positive control)

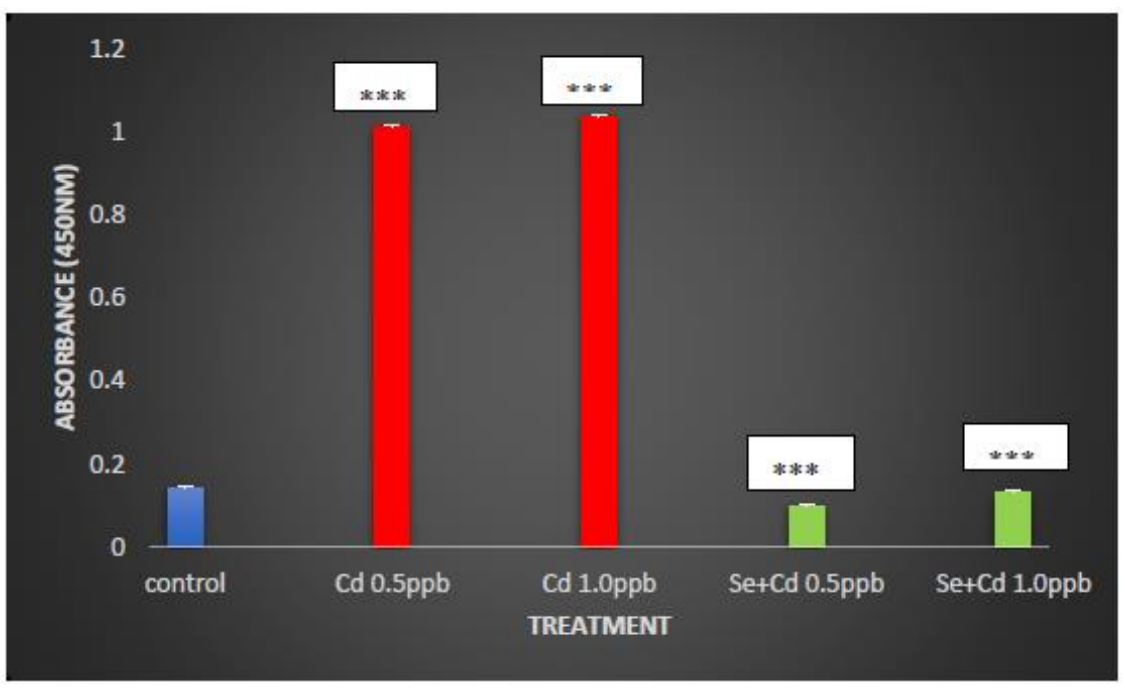

Chart 4. Control against $\mathrm{Cd}$ treatment 


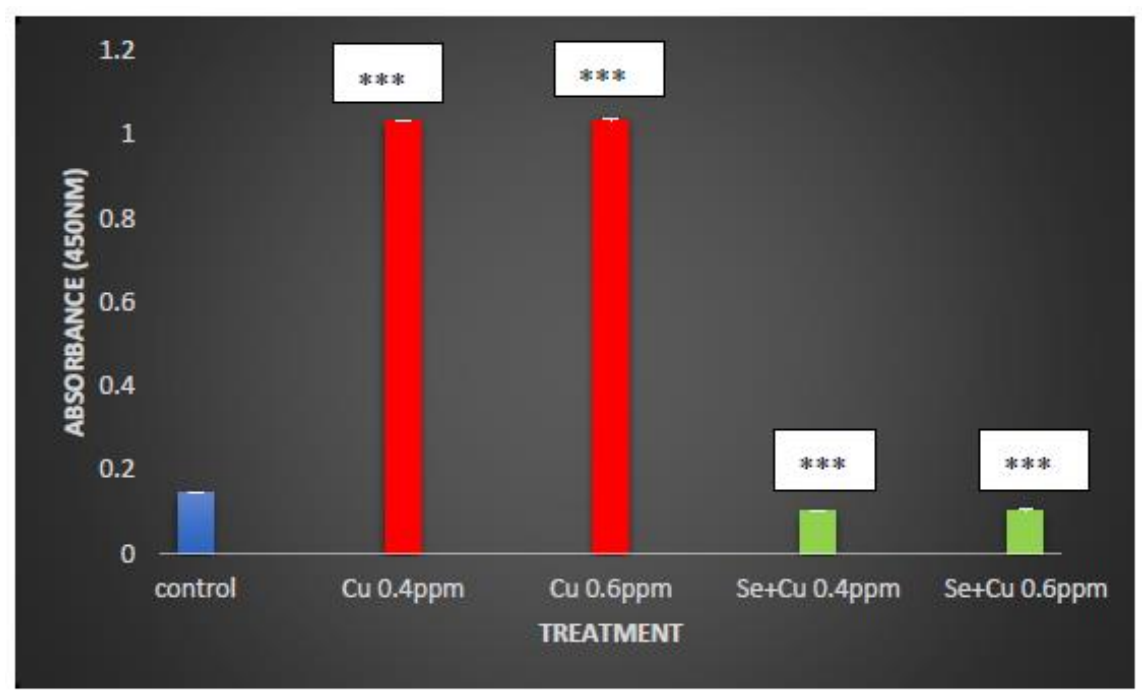

Chart 5. Se against $\mathrm{Cu}$ treatment

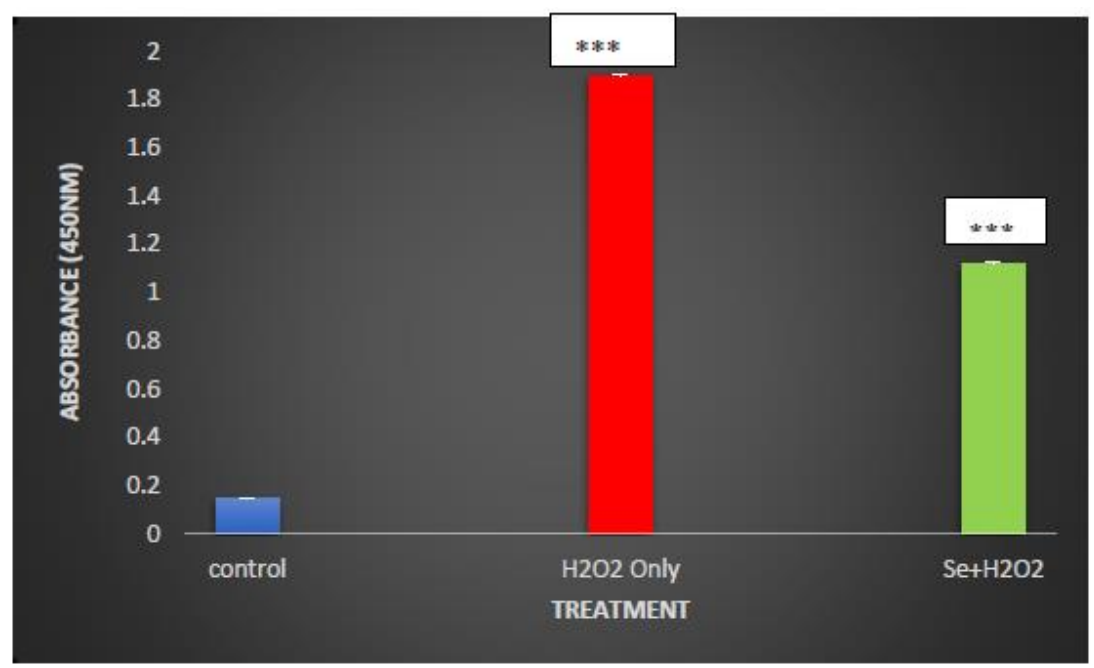

Chart 6. Control against Hydrogen Peroxide

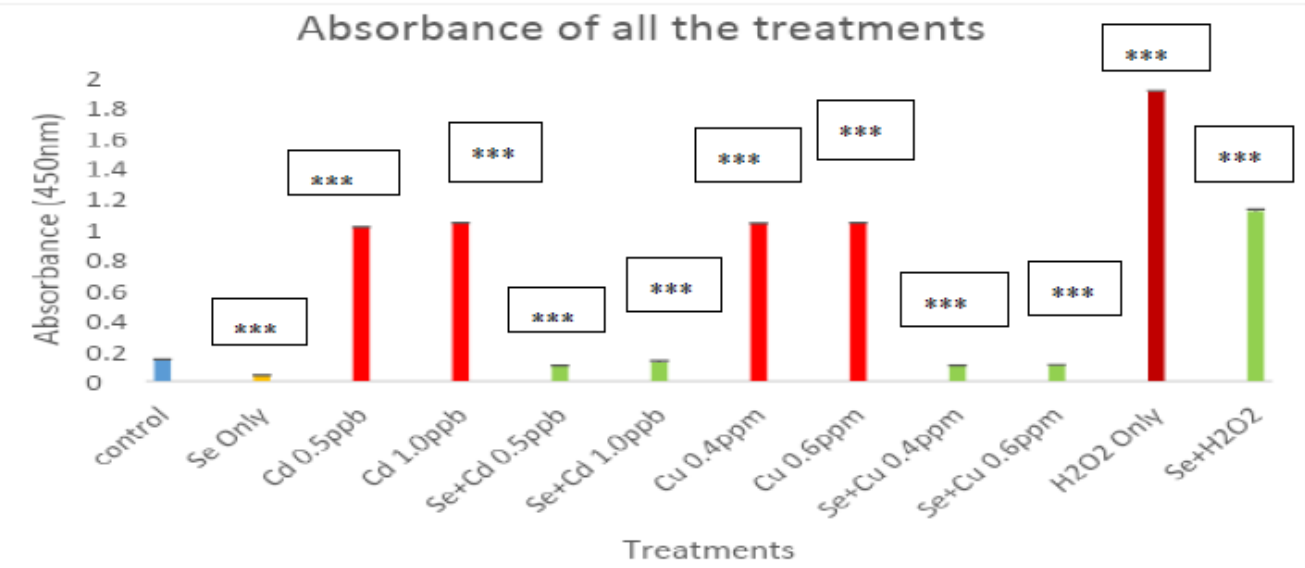

Graph 3. Comparison of SOD Absorbance 


\section{Macrothink}

\subsubsection{Catalase Assay}

Catalase is an enzymatic antioxidant that decomposes $\mathrm{H}_{2} \mathrm{O}_{2}$ produced as a result of oxidative stress to give $\mathrm{H}_{2} \mathrm{O}$ and $\mathrm{O}_{2}$. The result seen in this research agrees with Wahid et al who explained that catalase decomposes hydrogen peroxide and protects the cell tissues from hydroxyl free radicals, hence a decrease in catalase activity result in reduced metabolism in tardigrades due to the absorption of superoxide and hydrogen peroxide free radicals.

The assay was carried out using the Catalase (CAT) Assay Kit (Thermofisher) with manufacturer's instruction for cells. Using a 96 well plate, the standards, experimental samples, and treatments were plated. The plate was incubated for 30 minutes in room temperature and after gently mixing, the reaction mixture is monitored spectrophotometrically at 530-560 nm every 10 minute for $6 \mathrm{hrs}$ using a microplate reader. The value of absorbance reduced with increase in enzyme production, this result confirmed that the Se-treated organisms produced more antioxidative enzyme (CAT), due to the low absorbance reading (Chart 7-11 and graph 4-5).

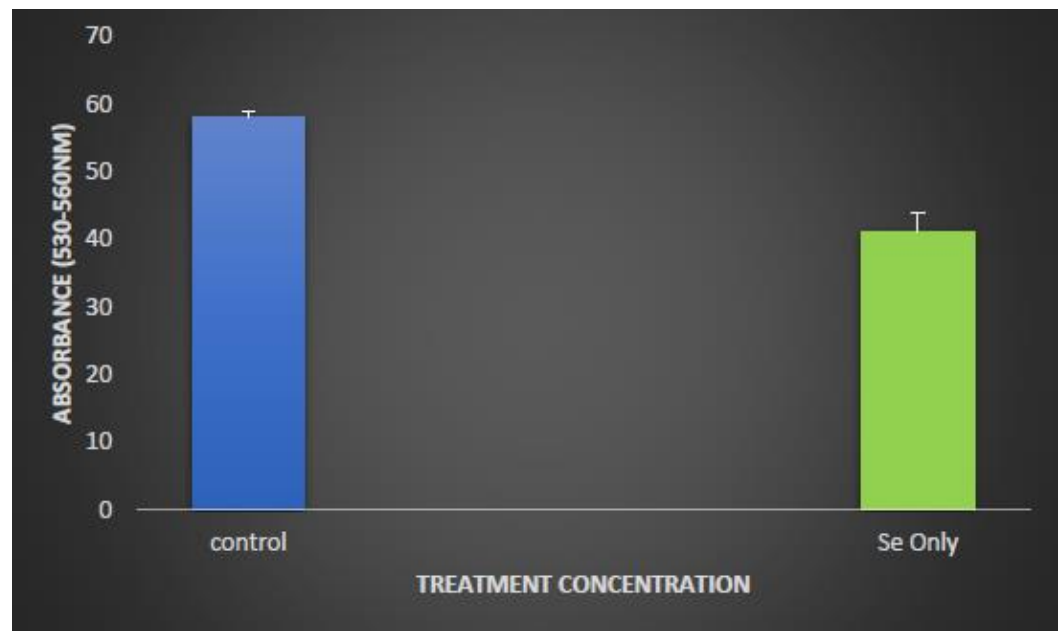

Chart 7. Control against Se

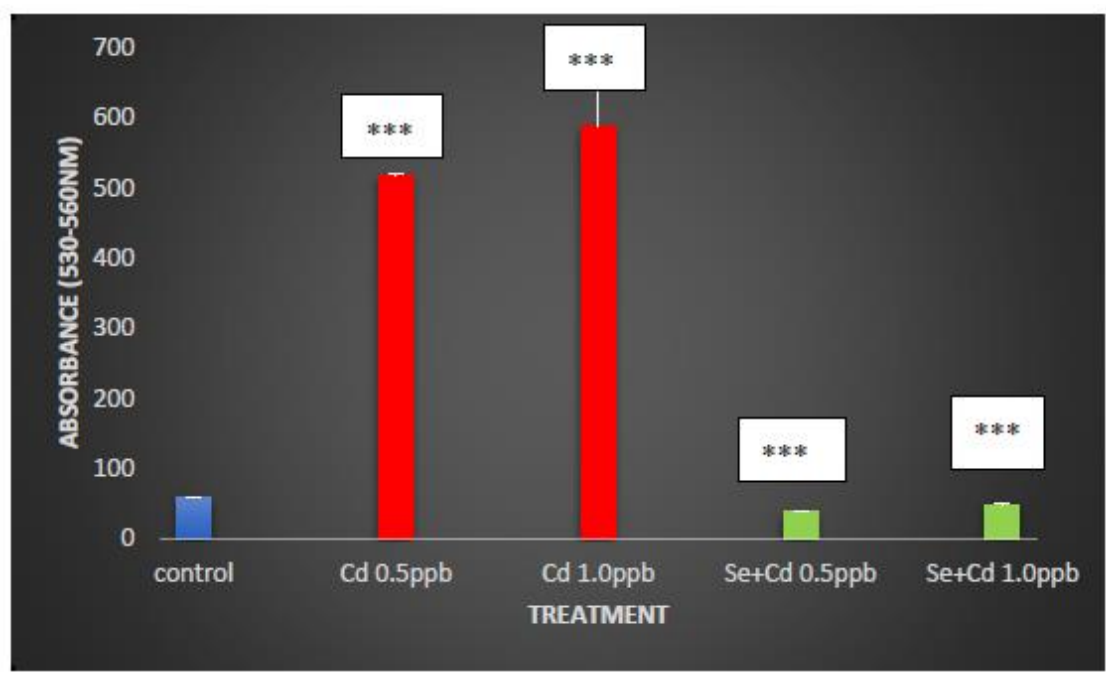

Chart 8. Control against $\mathrm{Cd}$ Treatment 


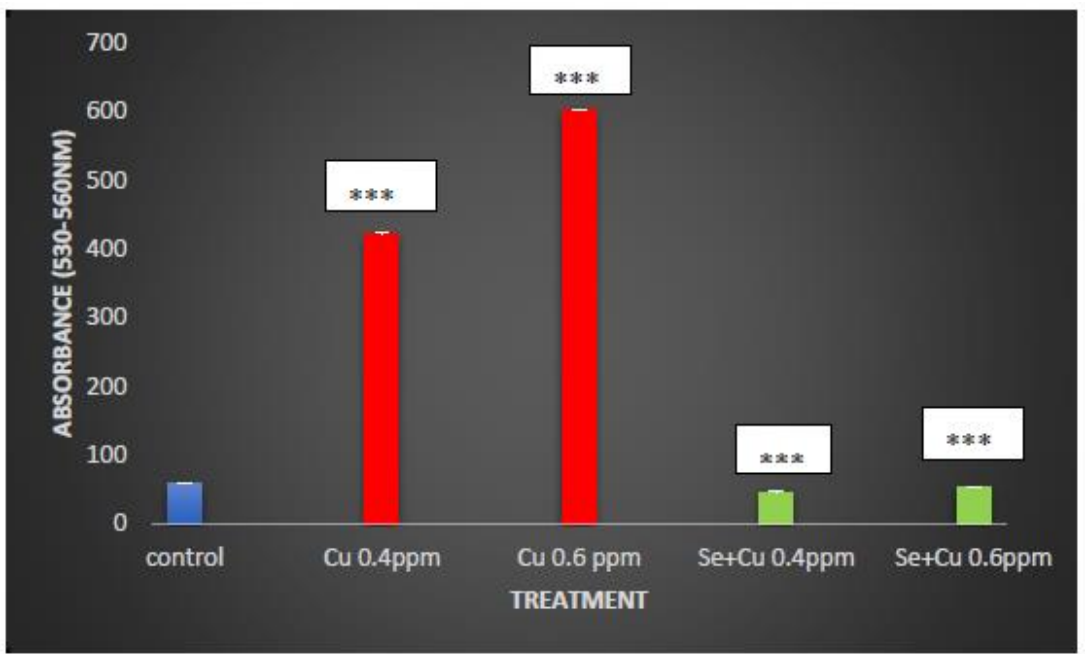

Chart 9. Control against $\mathrm{Cu}$ Treatment

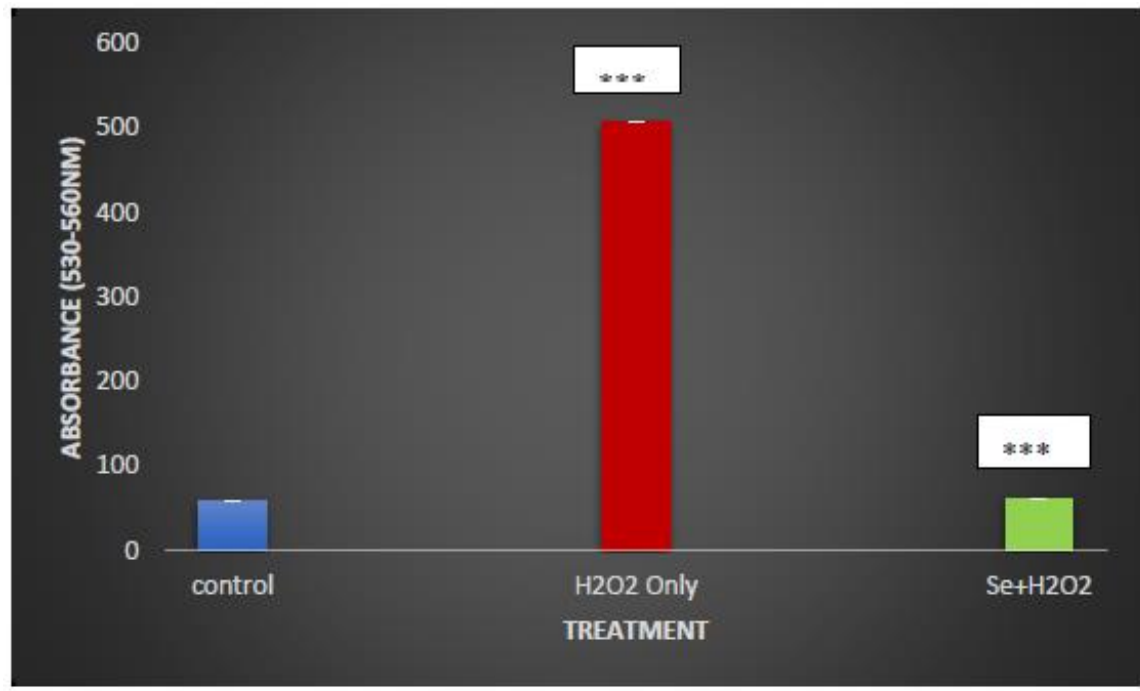

Chart 10. Control against Hydrogen Peroxide (Positive control)

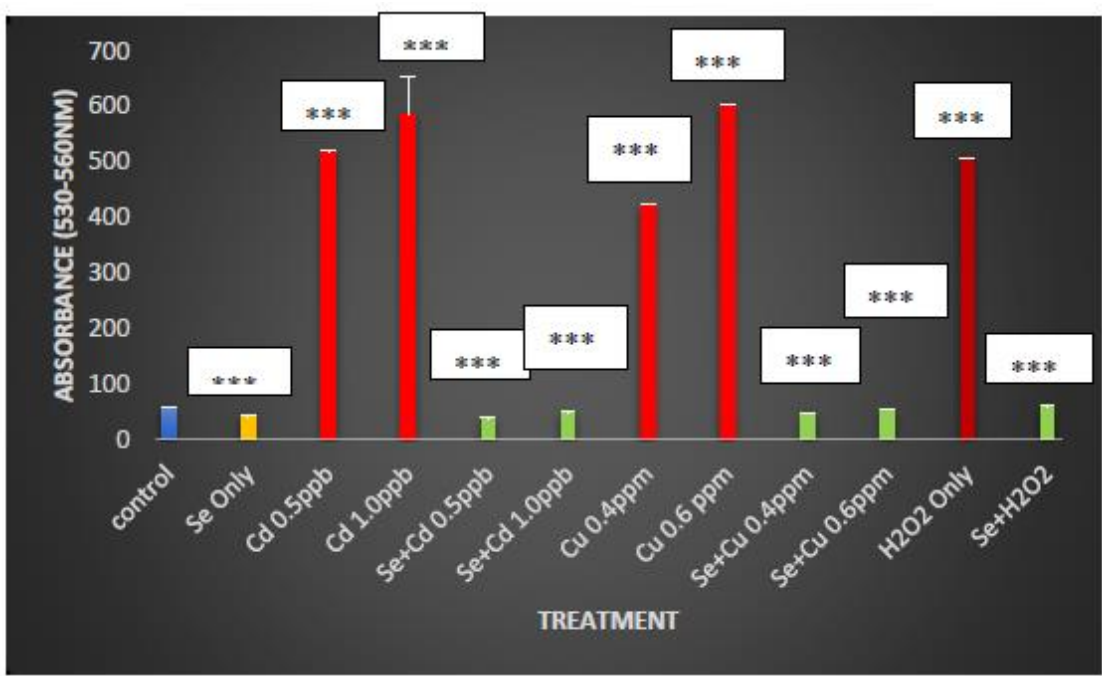

Chart 11. Absorbance of all the treatments 


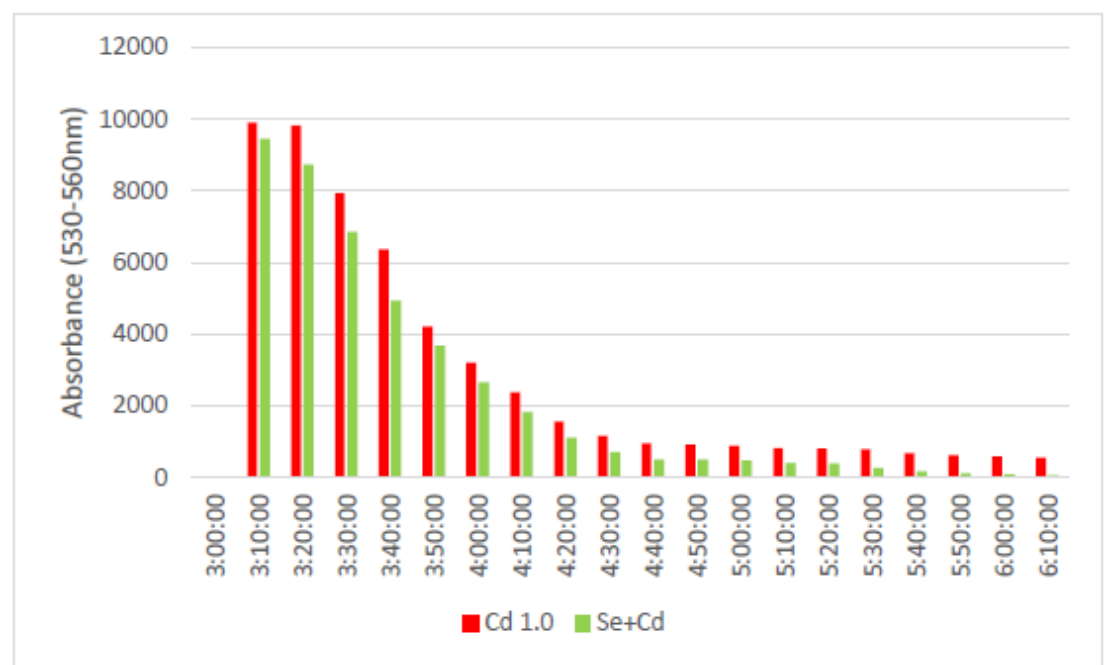

Graph 4. Absorbance of Cd treatment every 10 minutes

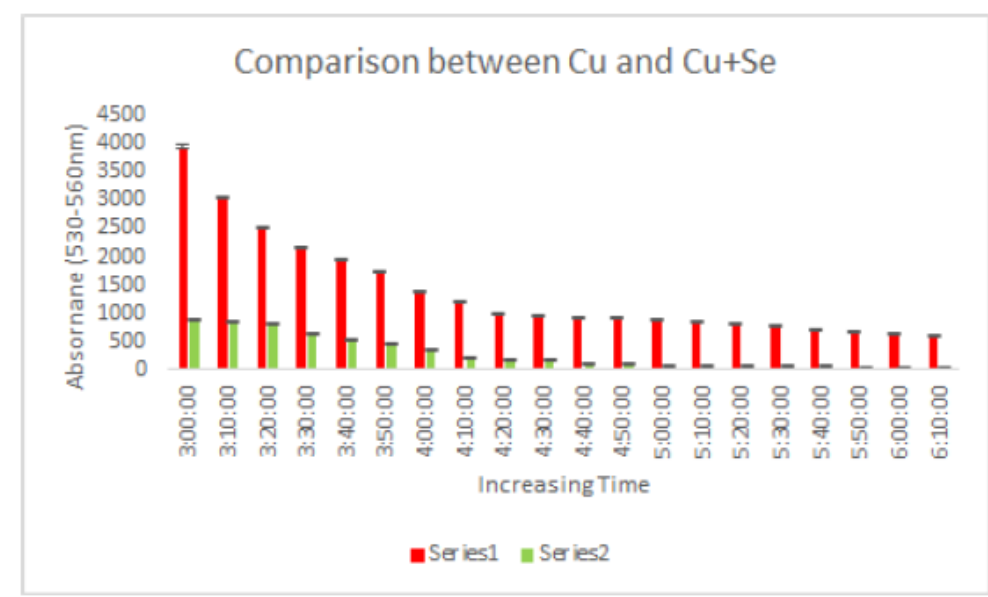

Graph 5. Absorbance of $\mathrm{Cu}$ treatment every 10 minutes

\subsubsection{Acetylcholine Assay}

Acetylcholine is a chemical that sends signal for muscle activation. $\mathrm{Cd}$ and $\mathrm{Cu}$ can cause harm by inactivating tardigrade muscles through their influence on the neuromuscular junction, hence the slowed movement in the exposed tardigrades can be traced to inadequate acetylcholine.

Acetylcholine Assay kit (Thermofisher) was used to detect the Acetylcholine in a fluorescence microplate reader. Using a 96 well plate, the standards, experimental samples, and treatments were plated. The plate was incubated for 30 minutes in room temperature and after gently mixing, the reaction mixture is monitored spectrophotometrically at 530-560. The fluorescence reading increased with an increase in enzyme production, this result confirmed that the Se-treated organisms produced more antioxidative enzyme ( $\mathrm{ACh})$, due to the high fluorescence reading as seen in Charts 12-14 below 


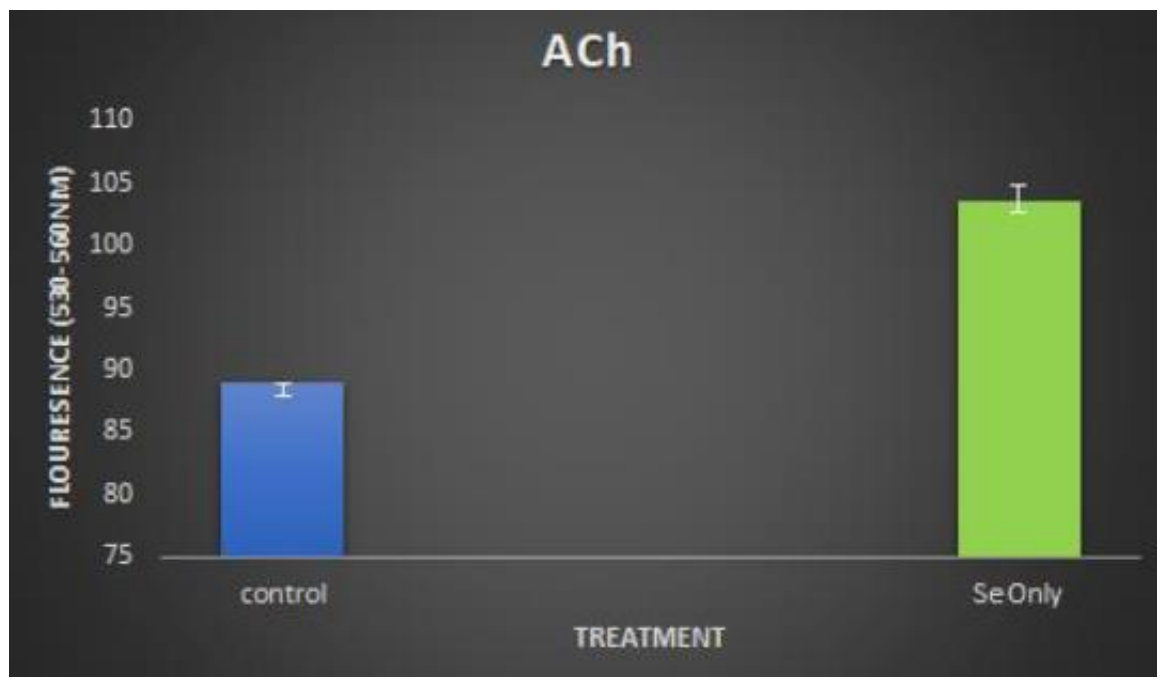

Chart 12. Control against Se

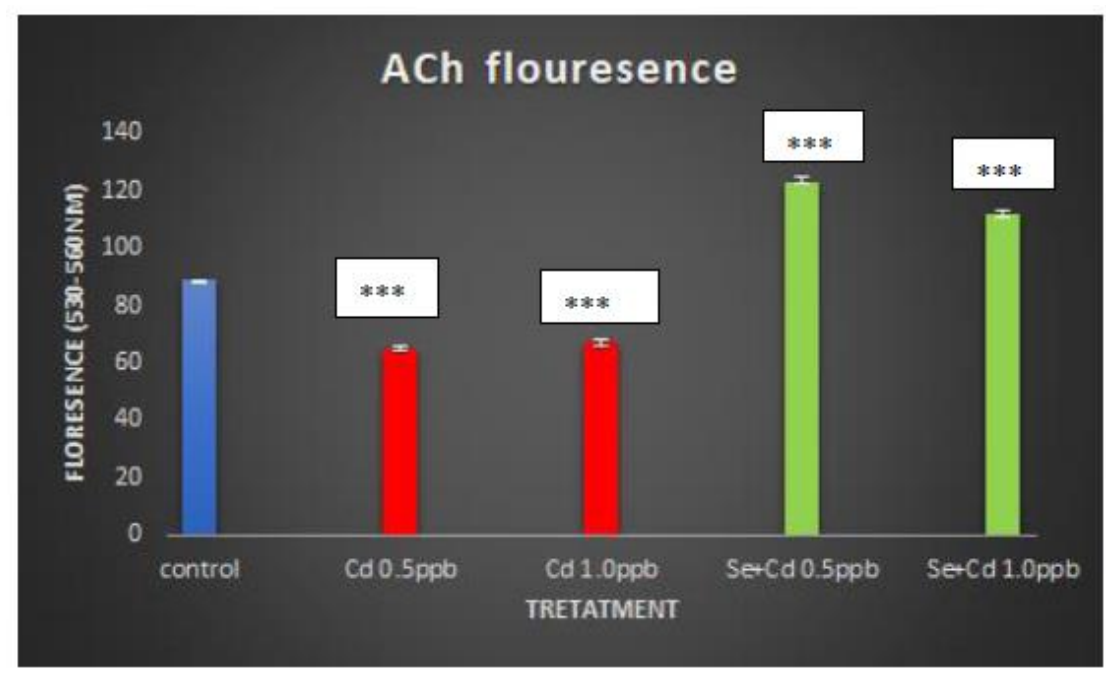

Chart 13. Control against Cd Treatment

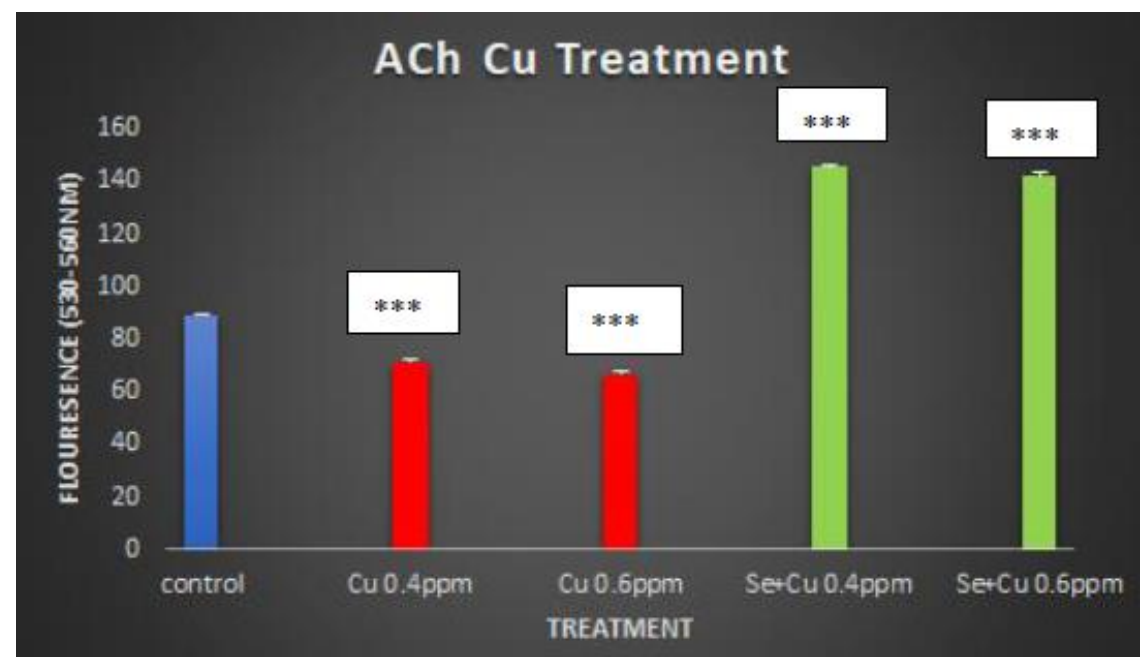

Chart 14. Control against $\mathrm{Cu}$ Treatment 


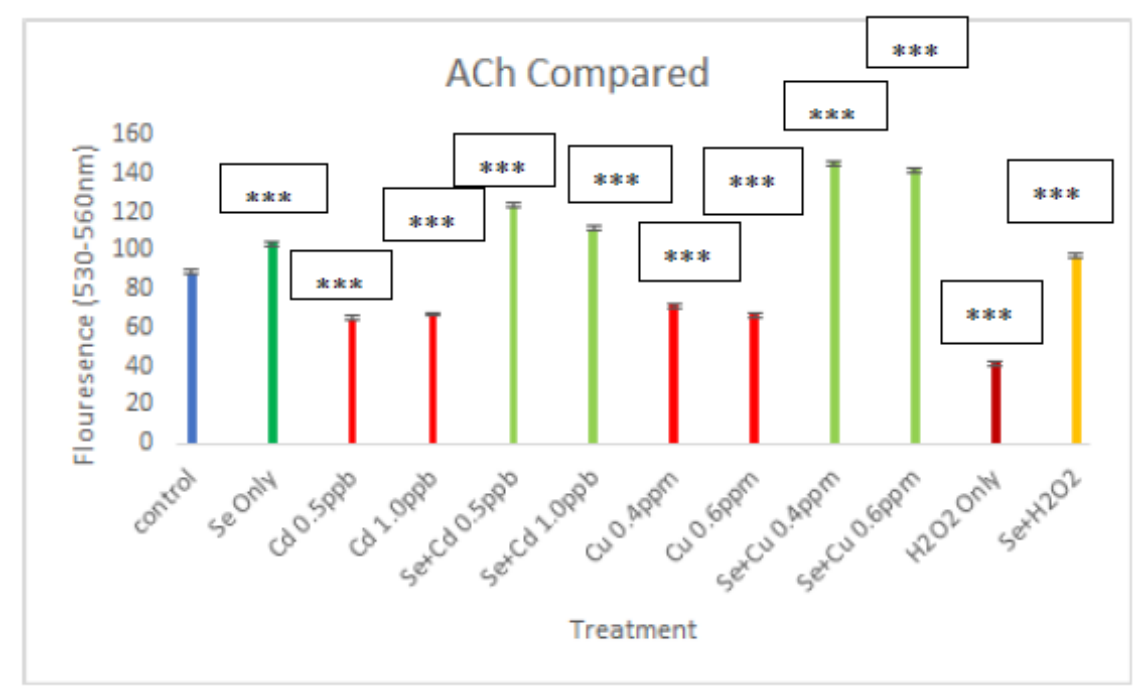

Graph 6. Comparison of ACh fluorescence

$* * * \mathrm{P}<0.001$

\section{Discussion}

Tardigrades are usually about $1 \mathrm{~mm}$ in size, the average size of the species used in this research was about $528 \mu \mathrm{m}$. It was observed that the morphology of the H. exemplaris was impacted by the $\mathrm{Cd}$ and $\mathrm{Cu}$ concentrations they were exposed to, as there was a reduction in size up to about $245 \mu \mathrm{m}$.

Studies have shown that tardigrades have resistance to a wide range of environments like high altitudes of over 19,600 feet, depths below the surface more than 15,000 feet, temperatures higher than 300 Fahrenheit and lower than minus 328 Fahrenheit. Their resistance is not limited to these extremes alone, they are known to also survive exposure to radiation, boiling liquids and pressure.

This research confirmed that heavy metals do have a high impact on the morphology and metabolic activities of $H$. exemplaris as they reduced in body size as seen by the size changes indicated by the orange-colored arrows in the images above and metabolic activities that dropped to $20 \%$ over the period of exposure to cadmium and copper.

Comparing the three enzymes produced, it was observed that catalase production was the most altered because functionally catalase prevents the effect of free radicals to the cell by transforming harmful superoxide radicals into hydrogen peroxide which later breaks down into water and oxygen, however, after the cadmium and copper exposure, there was a rapid oxidation of the fluorogenic probe producing fluorescence and more absorbance value when the enzyme was quantified.

Summarily, our findings suggest that exposure of Tardigrades to cadmium and copper results in a toxic effect that induces the release of antioxidative enzymes, however, continuous exposure overtime, reduces the production of the antioxidative enzyme resulting in harmful 
conditions in tardigrades. Treatment with Se, which is environmentally available, upregulates the antioxidative enzymes.

\section{Acknowledgments}

I want to appreciate the financial support received from Title III Award P031B090216; Historically Black Graduate Institutions (HBGI) (CFDA No. 84.0\#31B). A very big thank you to my lab mates, colleagues and Djene Keita Ph.D and professors for assisting with the manuscript preparation

\section{References}

Ahmed, M. K., Shaheen, N., Islam, M. S., Habibullah-al-Mamun, M., Islam, S., Mohiduzzaman, M., \& Bhattacharjee, L. (2015). Dietary intake of trace elements from highly consumed cultured fish (Labeo rohita, Pangasius pangasius and Oreochromis mossambicus) and human health risk implications in Bangladesh. Chemosphere, 128, 284-292.

https://doi.org/10.1016/j.chemosphere.2015.02.016

ATSDR. (2012). Toxicological profile for cadmium. Agency for Toxic Substances and Disease Registry (ATSDR). Atlanta, GA: U.S. Department of Health and Human Services, public health service. [Online] Available: https://www.atsdr.cdc.gov/toxprofiles/tp5.pdf

COWI, A. S (2003a). Nordic Council of Ministers. Cadmium review. pp. 1-24.

Environmental Protection Agency. (2015). EPA regulations for Selenium.

Hassler, C. S., Chafin, R. D., Klinger, M. B., \& Twiss, M. R. (2007). Application of the biotic ligand model to explain potassium interaction with thallium uptake and toxicity to plankton. Environmental Toxicology and Chemistry: An International Journal, 26(6), 1139-1145. https://doi.org/10.1897/06-315R.1

Hygum, T. L., Fobian, D., Kamilari, M., Jørgensen, A., Schiøtt, M., Grosell, M., \& Møbjerg, N. (2017). Comparative investigation of copper tolerance and identification of putative tolerance related genes in tardigrades. Frontiers in physiology, 8, 95.

https://doi.org/10.3389/fphys.2017.00095

Iheanacho, E. U., Ndulaka, J. C., \& Onuh, C. F. (2017). Environmental pollution and heavy metals. Environ Pollut, 5(5), 2321-9122.

Küçükbay, F. Z., Yazlak, H., Karaca, I., Sahin, N., Tuzcu, M., Cakmak, M. N., \& Sahin, K. (2009). The effects of dietary organic or inorganic selenium in rainbow trout (Oncorhynchus mykiss) under crowding conditions. Aquaculture Nutrition, 15(6), 569-576.

https://doi.org/10.1111/j.1365-2095.2008.00624.x

Liu, G. D., Sheng, Z., Hou, C. C., Ni, J., Han, Y. L., Wang, Y. F., ... Zhu, J. Q. (2017). Molecular cloning, characterization and expression analysis of metallothionein in the liver of the teleost Acrossocheilus fasciatus exposed to cadmium chloride. Environmental toxicology and pharmacology, 53, 1-9. https://doi.org/10.1016/j.etap.2017.03.020

Liu, H., Liu, G., Yuan, Z., Ge, M., Wang, S., Liu, Y., \& Da, C. (2019). Occurrence, potential 
health risk of heavy metals in aquatic organisms from Laizhou Bay, China. Marine pollution bulletin, 140, 388-394. https://doi.org/10.1016/j.marpolbul.2019.01.067

Macdonald, H. (2004). Geologic Puzzles: Morrison Formation. Starting Point. [Online] Available: http://serc.carleton.edu/introgeo/interactive/examples/morrisonpuzzle.html

Mao, X. W., Li, Y. Y., \& Lin, X. H. (2007). Investigation on pollutant of aquatic products in Guangzhou City. Chin J Health Lab Technol, 17, 2288-2290.

Martín-Folgar, R., \& Martínez-Guitarte, J. L. (2019). Effects of single and mixture exposure of cadmium and copper in apoptosis and immune related genes at transcriptional level on the midge Chironomus riparius Meigen (Diptera, Chironomidae). Science of the Total Environment, 677, 590-598. https://doi.org/10.1016/j.scitotenv.2019.04.364

Melstrom, P. C., \& Williams, P. L. (2007). Measuring movement to determine physiological roles of acetylcholinesterase classes in Caenorhabditis elegans. Journal of nematology, 39(4), 317.

Mesa-Herrera, F., Quinto-Alemany, D., \& Díaz, M. (2019). A Sensitive, Accurate, and Versatile Method for the Quantification of Superoxide Dismutase Activities in Biological Preparations. Reactive Oxygen Species, 7(19), 10-20. https://doi.org/10.20455/ros.2019.809

Mittler, R. (2017). ROS are good. Trends in plant science, 22(1), 11-19.

https://doi.org/10.1016/j.tplants.2016.08.002

Singh, R., Gautam, N., Mishra, A., \& Gupta, R. (2011). Heavy metals and living systems: An overview. Indian journal of pharmacology, 43(3), 246-253.

https://doi.org/10.4103/0253-7613.81505

Valdés, J., Guiñez, M., Castillo, A., \& Vega, S. E. (2014). Cu, Pb, and Zn content in sediments and benthic organisms from San Jorge Bay (northern Chile): Accumulation and biotransference in subtidal coastal systems. Ciencias Marinas, 40(1), 45-58.

https://doi.org/10.7773/cm.v40i1.2318

Wang, X., Shen, Z., Wang, C., Li, E., Qin, J. G., \& Chen, L. (2019). Dietary supplementation of selenium yeast enhances the antioxidant capacity and immune response of juvenile Eriocheir Sinensis under nitrite stress. Fish \& shellfish immunology, 87, 22-31. https://doi.org/10.1016/j.fsi.2018.12.076

Wang, Y., Han, J., Li, W., \& Xu, Z. (2007). Effect of different selenium source on growth performances, glutathione peroxidase activities, muscle composition and selenium concentration of allogynogenetic crucian carp (Carassius auratus gibelio). Animal feed science and technology, 134(3-4), 243-251. https://doi.org/10.1016/j.anifeedsci.2006.12.007

Wang, Z., Wang, M., Han, H., \& Jiang, D. (2004). Survey on the cadmium levels in fish, crustaceans and bivalve mollusks in China of 2002. Journal of hygiene research, 33(4), 473-474.

Weronika, E., \& Łukasz, K. (2017). Tardigrades in Space Research - Past and Future. Orig 


\section{Macrothink \\ Environmental Management and Sustainable Development \\ ISSN 2164-7682 \\ 2022, Vol. 11, No. 2}

Life Evol Biosph, 47, 545-553. https://doi.org/10.1007/s11084-016-9522-1

World Health Organization. (2018). A global overview of national regulations and standards for drinking-water quality.

Wahid, A., Mahmoud, S. M. N., Attia, E. Z., Yousef, A. S., Okasha, A. M. M., \& Soliman, H. A. (2020). Dietary fiber of psyllium husk (Plantago ovata) as a potential antioxidant and hepatoprotective agent against CCl4-induced hepatic damage in rats. South African Journal of Botany, 130, 208-214. https://doi.org/10.1016/j.sajb.2020.01.007

Yang, J., Liu, D., Dahms, H. U., \& Wang, L. (2015). Cadmium inhibits the vitellogenesis of freshwater crab Sinopotamon henanense. Environmental toxicology and chemistry, 34(7), 1609-1616. https://doi.org/10.1002/etc.2958

Zhou, Y., Luo, Z., \& Wang, L. (2019). Modulation of oxidative damage by lipopolysaccharides and antioxidant responses in the freshwater crab Sinopotamon henanense Bott 1967 (Decapoda: Brachyura: Potamonidae) during cadmium exposure. Journal of Crustacean Biology. https://doi.org/10.1093/jcbiol/ruz035

Zitoun, R., Clearwater, S. J., Hassler, C., Thompson, K. J., Albert, A., \& Sander, S. G. (2019). Copper toxicity to blue mussel embryos (Mytilus galloprovincialis): The effect of natural dissolved organic matter on copper toxicity in estuarine waters. Science of the Total Environment, 653, 300-314. https://doi.org/10.1016/j.scitotenv.2018.10.263

\section{Copyright Disclaimer}

Copyright for this article is retained by the author(s), with first publication rights granted to the journal.

This is an open-access article distributed under the terms and conditions of the Creative Commons Attribution license (http://creativecommons.org/licenses/by/4.0/). 